\title{
Porosity Development Controlled by Deep-Burial Diagenetic Process in Lacustrine Sandstones Deposited in a Back-Arc Basin (Makó Trough, Pannonian Basin, Hungary)
}

\author{
Emese Laczkó-Dobos $\mathbb{D}^{1,2}$ Susanne Gier $\mathbb{D}^{3},{ }^{3}$ Orsolya Sztanó $\mathbb{D},{ }^{4}$ Rastislav Milovský $\mathbb{D},{ }^{5}$ \\ and Kinga Hips $\mathbb{1}^{2}$ \\ ${ }^{1}$ Eötvös Loránd University, Pázmány Péter sétány 1/c, 1117 Budapest, Hungary \\ ${ }^{2}$ MTA-ELTE Geological, Geophysical and Space Science Research Group, H-1117 Budapest, Pázmány P. sétány 1/c, Hungary \\ ${ }^{3}$ Department of Geodynamics and Sedimentology, Universität Wien, Austria \\ ${ }^{4}$ Department of Geology, Eötvös Loránd University, Pázmány Péter sétány 1/c, 1117 Budapest, Hungary \\ ${ }^{5}$ Earth Science Institute of the Slovak Academy of Sciences, Banská Bystrica, Ďumbierska 1, Slovakia
}

Correspondence should be addressed to Emese Laczkó-Dobos; meseszocs@caesar.elte.hu

Received 4 February 2020; Revised 28 October 2020; Accepted 5 November 2020; Published 11 December 2020

Academic Editor: Rudy Swennen

Copyright (C) 2020 Emese Laczkó-Dobos et al. This is an open access article distributed under the Creative Commons Attribution License, which permits unrestricted use, distribution, and reproduction in any medium, provided the original work is properly cited.

\begin{abstract}
Deeply buried Pannonian (Upper Miocene) siliciclastic deposits show evidence of secondary porosity development via dissolution processes at a late stage of diagenesis. This is demonstrated by detailed petrographic (optical, cathodoluminescence, fluorescence, and scanning electron microscopy) as well as elemental and stable isotope geochemical investigations of lacustrine deposits from the Makó Trough, the deepest depression within the extensional Pannonian back-arc basin. The analyses were carried out on core samples from six wells located in various positions from centre to margins of the trough. The paragenetic sequence of three formations was reconstructed with special emphasis on sandstone beds in a depth interval between ca 2700 and $5500 \mathrm{~m}$. The three formations consist, from bottom to top, of (1) open-water marls of the Endröd Formation, which is a hydrocarbon source rock with locally derived coarse clastics and (2) a confined and (3) an unconfined turbidite system (respectively, the Szolnok and the Algyö Formation). In the sandstones, detrital grains consist of quartz, feldspar, and mica, as well as sedimentary and metamorphic rock fragments. The quartz content is high in the upper, unconfined turbidite formation (Algyö), whereas feldspars and rock fragments are more widespread in the lower formations (Szolnok and Endröd). Eogenetic minerals are framboidal pyrite, calcite, and clay minerals. Mesogenetic minerals are ankerite, ferroan calcite, albite, quartz, illite, chlorite, and solid bituminous organic matter. Eogenetic finely crystalline calcite yielded $\delta^{13} C_{\mathrm{V}-\mathrm{PDB}}$ values from 1.4 to $0.7 \%$ and $\delta^{18} O_{\mathrm{V}-\mathrm{PDB}}$ values from -6.0 to $-7.4 \%$, respectively. Mesogenetic ferroan calcite yielded $\delta^{13} C_{\mathrm{V}-\mathrm{PDB}}$ values from 2.6 to $-1.2 \%$ and $\delta^{18} O_{\mathrm{V}-\mathrm{PDB}}$ values from -8.3 to $-14.0 \%$, respectively. In the upper part of the turbidite systems, remnants of the migrated organic matter are preserved along pressure dissolution surfaces. All these features indicate that compaction and mineral precipitations resulted in tightly cemented sandstones prior to hydrocarbon migration. Interconnected, secondary, open porosity is associated with pyrite, kaolinite/dickite, and postdates of the late-stage calcite cement. This indicates that dissolution processes took place in the deep burial realm in an extraformational fluid-dominated diagenetic system. The findings of this study add a unique insight to the previously proposed hydrological model of the Pannonian Basin and describe the complex interactions between the basinal deposits and the basement blocks.
\end{abstract}

\section{Introduction}

Porosity development of turbidite sandstones in burial depth greater than $3000 \mathrm{~m}$ is a key issue in understanding their potential for hydrocarbon exploration. Reservoir quality of sandstones is controlled by primary sedimentary characteristics that can be significantly modified by diagenetic alterations [1-7]. Case studies of the diagenetic evolution of 
tight sandstone reservoirs, from the USA, China, and Germany [8-14], highlight some common features. Diagenetic processes that significantly influencing reservoir quality are compaction, quartz, and carbonate cementation and clay mineral transformations. Preservation of primary porosity is generally assigned to early formation of chlorite coats or early developing overpressure [15-17]. Secondary porosity development is commonly connected to the dissolution of unstable minerals. Although dissolution and/or precipitation of certain clay minerals can preserve or even enhance porosity, the latter processes in many cases led to the decrease of permeability [18].

Basin-centered gas accumulations typically consist of sandstone reservoirs of large extent but very low permeability [19]. They are usually characterized by abnormally high pressure and lack of a definitive gas-water contact [19]. Tight sandstones are defined as reservoirs with low porosity $(<10 \%)$, low permeability $(<0.1 \mathrm{mD})$, and complex pore structures and heterogeneity [11, 20-22]. In the early 2000s, unconventional hydrocarbon exploration focused on potential basin-centered gas and shale-gas accumulations in the Upper Miocene deposits of the Makó Trough [23]. Although the exploration activity did not result in any economic discoveries, it allowed gathering vast amounts of samples and data [24]. Studies focused on the sedimentary architecture, geophysical, and organic geochemical properties of these deposits $[23,25,26]$. Diagenetic components were described, and alteration processes were interpreted from cores of legacy wells like Hódmezővásárhely-I [27].

This study investigates deeply buried Upper Miocene lacustrine sandstones from the Makó Trough, the deepest portion of the Pannonian Basin proper, from a depth of 2700 to $5500 \mathrm{~m}$ with temperatures of 90 to $220^{\circ} \mathrm{C}$, respectively, [28]. It focuses on the diagenetic history and porosity evolution of three formations, the Endrőd, Szolnok, and Algyő Formations, representing open-water marls with locally derived coarse clastics, the overlying strongly confined basin-centered turbidite system, and an upper, slope-related unconfined turbidite system, respectively. The marls are the source rocks, and the sandstones of the lower turbidite system are tight, whereas the sandstones of the upper turbidite system show conventional or semiconventional reservoir properties [23]. This study highlights differences in the porosity evolution of the two successive turbidite sandstone units. Sandstone samples from cores of six wells were studied by petrographic methods (optical, cathodoluminescence, fluorescence, and scanning electron microscopy) using thin sections and small broken pieces. Additionally, the elemental and stable isotope composition of diagenetic calcite phases was analyzed. The main objectives of the research include (1) petrographic characterization of sandstones, (2) geochemical evaluation of calcite phases, (3) interpretation of the paragenetic sequence, (4) interpretation of the diagenetic processes, which controlled the reservoir quality, and (5) evaluation of the fluid flow model.

\section{Geological Setting}

The studied succession was deposited in Lake Pannon (Figure 1), in an endorheic lacustrine system of brackish water [29]. It became isolated from the Paratethys $11.6 \mathrm{Ma}$ ago as a result of the uplift of the Alpine-Carpathian orogenic belt $[30,31]$. The lake existed for about $7 \mathrm{Ma}$ and had a variety of coexisting depositional environments [32]. During the approximately first two million years, the lake became successively deeper and larger, but at about $10 \mathrm{Ma}$, normal regression began. Rivers entered the lake from uplifting orogens to the NW, N, and NE. As a result, the lake basin was gradually filled with open-water marls, sandy turbidites, silty slope deposits, stacked deltas, and alluvial deposits [25, 30], comprising five successive formations. The Endröd Formation is characterized by open-water marls with intercalations of locally derived, sediment gravity-flow deposits, conglomerates, pebbly, silty sandstones, and sandstones [33]. The Szolnok Formation is a turbidite system resulting from the deposition of sand up to an overall thickness of $1000 \mathrm{~m}$ locally. Provenance studies indicate the distal AlpineCarpathian source of these sands [34]. The uppermost turbidite system can be directly linked to the feeder shelf-slope, seismically mirrored by large clinoforms of the Algyö Formation. These are overlain by deltaic successions of the Ujfalu Formation and alluvial deposits of the Zagyva Formation. Well Makó-7 (M7) near the central, yet not the deepest part of Makó Trough, demonstrates that the thickness of the deep-water lacustrine deposits (the lower three formations) attains $3500 \mathrm{~m}$, whereas the total thickness of Upper Miocene to Quaternary succession exceeds $6000 \mathrm{~m}$ locally [25].

Lake Pannon occupied the area of the Pannonian Basin, where the back-arc extension resulted in the opening of a significant number of subbasins separated by uplifted basement highs $[35,36]$. The main location of extension migrated in space and time from west to east and from late Early Miocene until early Late Miocene [35]. The Makó Trough is one of the youngest subbasins and the deepest depocenter of the Pannonian Basin, the outline of which is defined by basement highs (Figure 1). Balázs et al. [37] reconstructed the subsidence history of the Makó Trough based on palaeontological, seismic, and well data (Figure 2). The Makó Trough, as a half-graben, was characterized by rapid and continuous late Miocene synrift subsidence, not obser8ved in other subbasins of the Pannonian Basin. This resulted in extreme water depth, low sediment flux, and undisturbed "pelagic" sedimentation [25, 37].

Present-day temperature at the top of the Algyö Formation $(\sim 2500 \mathrm{~m})$ is $100^{\circ} \mathrm{C}$, whereas at the bottom of the Endröd Formation $(5500 \mathrm{~m})$, it is $210^{\circ} \mathrm{C}$ [24]. Heat flow values are as high as $100-130 \mathrm{~mW} / \mathrm{m}^{2}$ [38]. As a consequence of the high temperatures, the petroleum system is dynamic, and source rocks are actively generating and charging reservoirs [39]. The dynamic nature of the hydrocarbon system has resulted in the development of pore pressures in excess of hydrostatic pressure [39]. The synrift phase was coeval with the deposition of deep-water sediments of the 1500 m-thick Endröd Formation (Figure 3). The overlying Szolnok Formation represents the immediate postrift, whereas the Algyő and Ujfalu Formations were deposited in the late postrift phase [35].

The lithology of the basin centre and slope deposits is documented by seven well logs and $182 \mathrm{~m}$ of core material (Figure 4 [25];). The lowermost studied unit is the Endröd 


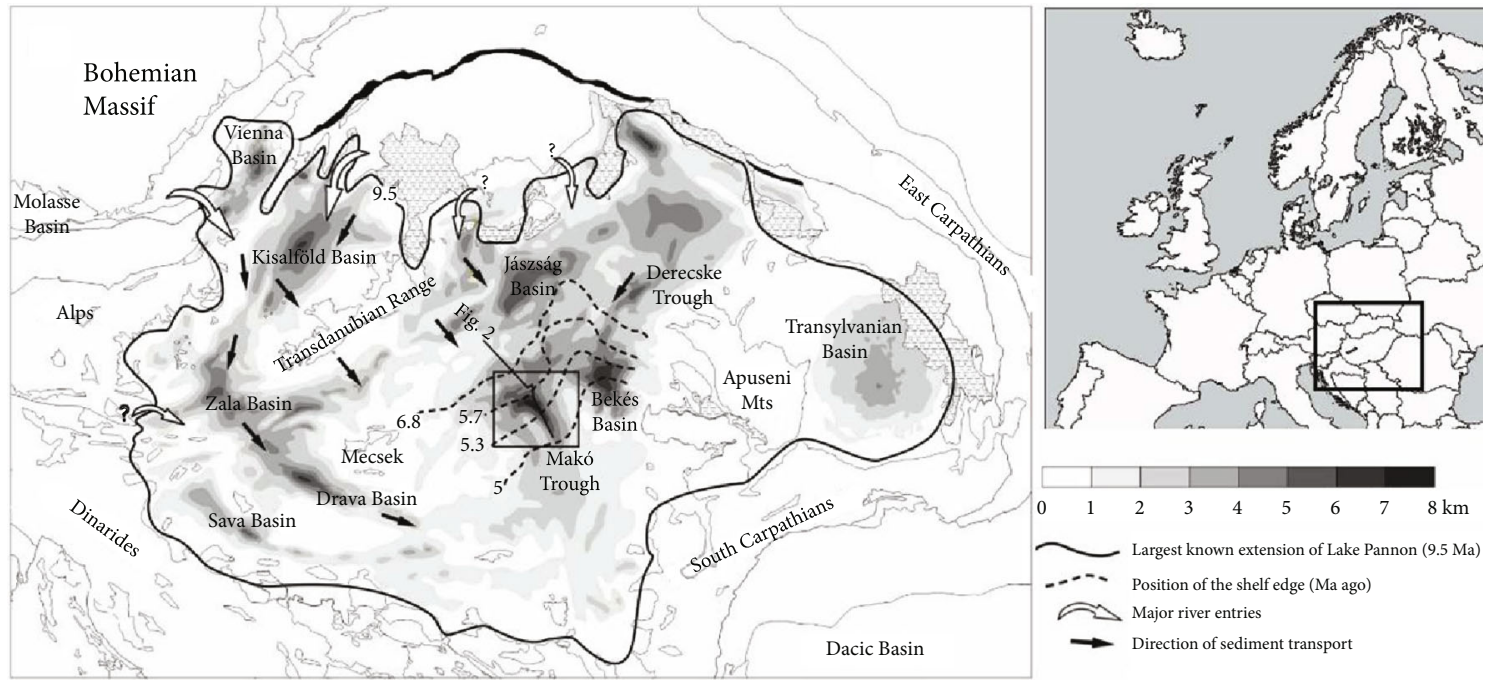

(a)

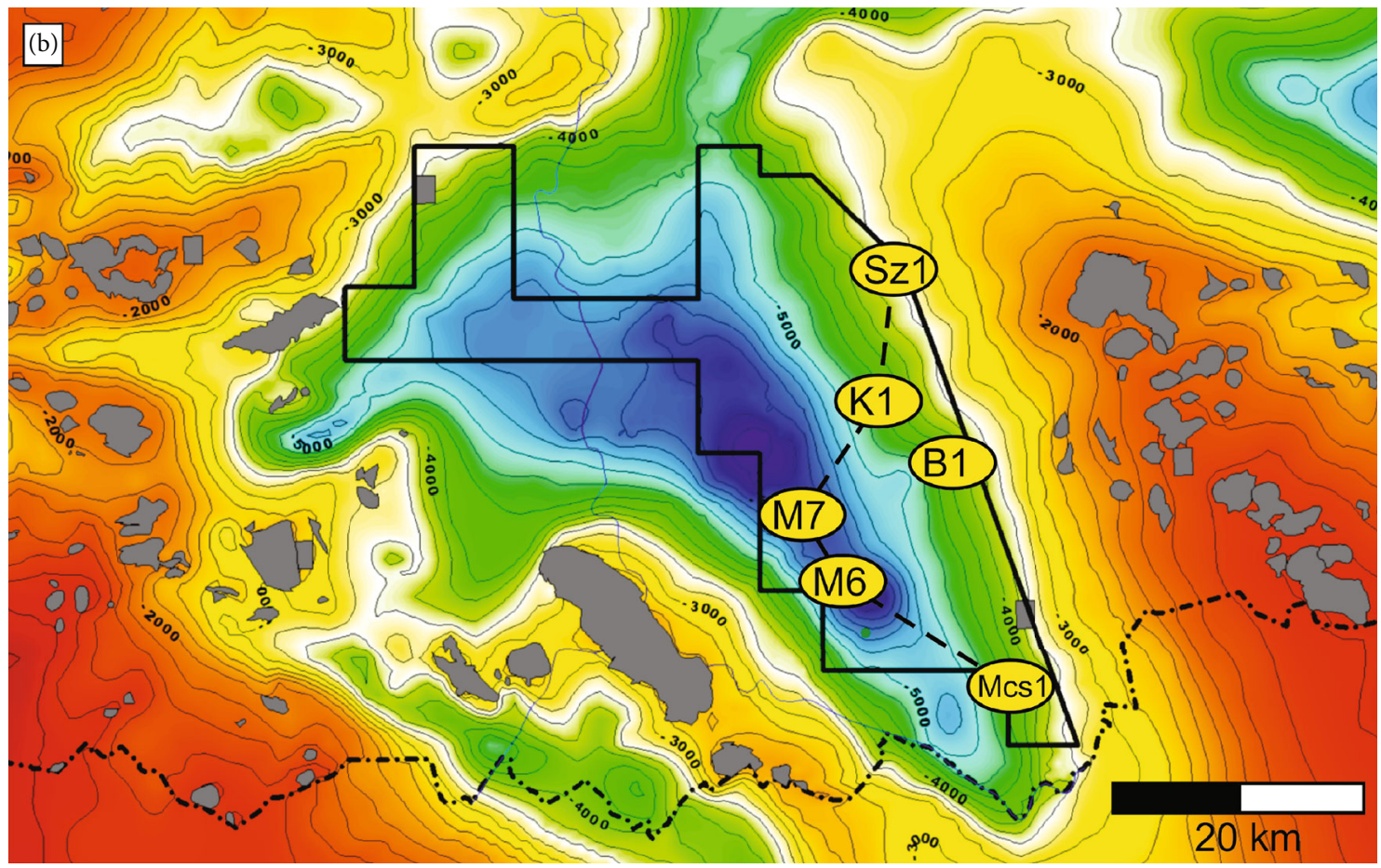

(b)

Figure 1: Maps of the studied area. (a) Depth of the Neogene basement of the Pannonian Basin [40]. The thick line indicates the largest known extension of Lake Pannon 9.5 Ma ago, whereas the dashed lines mark the position of the shelf-edge at between $6.8 \mathrm{Ma}$ and $5 \mathrm{Ma}$ [30]. White and black arrows indicate major rivers entering the basin and main direction of the sediment transport, respectively [25]. Rectangle shows the location of map on (b). (b) Map of Neogene basement depths and highs with the location of the Makó Trough; the studied wells are marked by yellow [41]. Location of the seismic line (Figure 4) is indicated by a dashed line. Oil and gas fields are indicated with green and red colors, respectively. Inset map shows Europe and the location of map (a) (rectangle). Hydrocarbon fields are indicated with grey color.

Formation. It starts with a $500 \mathrm{~m}$-thick interval of siltstones with thin sandstone interbeds. This facies is only described in the central part of the trough. The middle part consists of a $500 \mathrm{~m}$-thick succession of black calcareous marls comprising source rock intervals. It also includes turbiditic sandstones and matrix-supported conglomerates, such as debrites. The grains of these thick interbeds were supplied locally, from the subaerially exposed neighboring basement highs. The upper third of the Endröd Formation is made up of ca $500 \mathrm{~m}$-thick clay marls with rare sandy interbeds redeposited from the flanks of the meanwhile flooded highs $[25,33]$. Deposits of the main basin-centered, confined turbidite system (Szolnok Formation) are $1000 \mathrm{~m}$ in thickness and are made up of predominantly fine-grained, thin- to thick- 


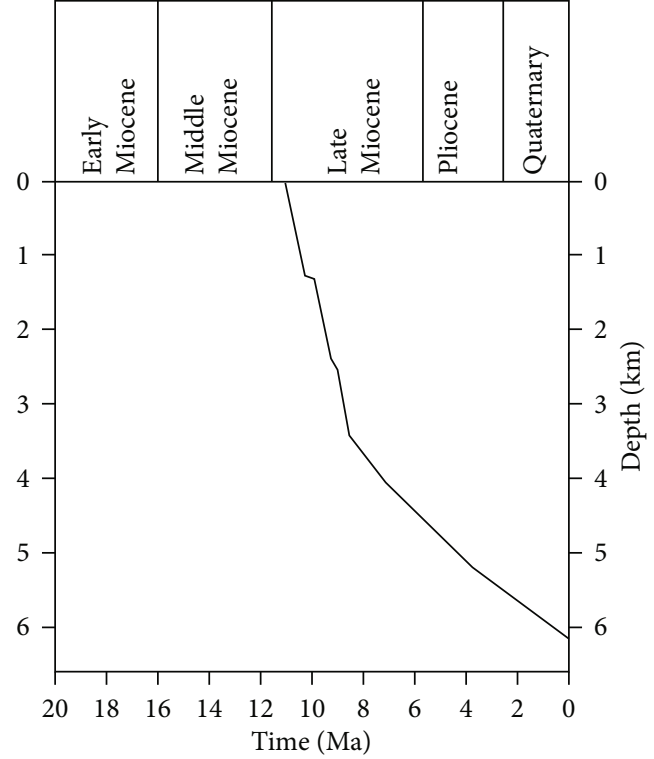

Figure 2: Subsidence curve of the Makó Trough by Balázs et al. (2017) [37] shows a very short and rapid synrift subsidence of the basement during early Late Miocene.

bedded amalgamated sandstones. In general, this formation is clay poor. Mudstone units are usually less than a few meters thick and are located between sandy lobe units with an individual thickness of 50-80 m [25]. Higher up in the succession, the abundance of mud-rich sandstone beds, i.e., hybrid event beds, increases. This indicates the decrease of confinement [33]. The Szolnok Formation is laterally continuous through the basin and pinches out on the flanks of the highs. The overlying Algyő Formation has two characteristic lithological units: the lower one is comprised of fine-grained sandstone units of $20-50 \mathrm{~m}$ in thickness, separated by several tens of metre-thick siltstones; the upper one is made up of claystones and siltstones that represent the progradational shelf-slope system $[23,25,33]$. The lobes and the thick siltstone intervals near the base of the slope indicating free spreading and switching of the unconfined system $[25,33]$.

2.1. Petrography and Diagenesis of Lacustrine Deposits in the Makó Trough. Petrographic and geochemical analyses of the calcareous marls and sandstones in the lower part of the Endröd Formation were provided by Varga et al. [42]. The authors interpreted immature clast composition with local provenance. The described paragenetic sequence is comprised of framboidal pyrite and calcite connected to cementation during shallow burial, and replacive dolomite, ankerite, and illite connected to a deep burial realm. In deeper part of the basin, the natural gas is rich in $\mathrm{H}_{2} \mathrm{~S}$ and in organosulphur [26]. Above $4500 \mathrm{~m}$, isotopically, heavy sulphur ( -4.7 to $34.9 \%$ ), cubic and finely crystalline pyrite, solid bitumen, and minor amounts of anhydrite are present. Based on these components, a zone of thermochemical sulphate reduction (TSR) was identified [26, 43].

Petrography and stable isotopes of the diagenetic components of sandstones of the Szolnok Formation were analyzed from lower turbiditic sandstones (Szolnok Formation) from three shallow-buried and one deeply-buried (Makó Trough) subbasins by Mátyás and Matter [44] and Mátyás [27]. Comparing the areas with different burial histories revealed that early-stage meteoric water influence, resulting in secondary open porosity formed by feldspar dissolution, was significant during the diagenesis of shallow-buried deposits. The predominant diagenetic minerals in sandstones are ankerite, kaolinite, and siderite, whereas calcite is subordinate. In contrast, in the deeply buried subbasin, the deposits were affected by compactional fluids. The paragenesis is dominated by calcite, chlorite, and illite. No extensive porosity redistribution is documented. The observed diagenetic components are typical for chemical transformations within the sandstonemudstone couplets.

Porosity values in the Endröd and Szolnok Formation are below $5 \%$, whereas permeability values are below $0.01 \mathrm{mD}$. In the uppermost part of the Szolnok Formation and in the Algyő Formations, porosity and permeability values are up to one to two magnitudes higher, $10-15 \%$, and $>1 \mathrm{mD}$, respectively (Figure 4).

2.2. Hydrocarbon System of the Makó Trough. The Endröd Formation has an original TOC of 1.25-1.5 wt\% [45] and contains type III and type II-III kerogens [46, 47]. Vitrinite reflectance is $2.0-2.2 \% R_{\mathrm{o}}$. In the Neogene of the Pannonian Basin, the oil generation window is located in a depth range of 2.4-4.3 km [40, 47]. Badics et al. [24] estimated the generated volume of hydrocarbons in the Makó Trough by assessing the hydrocarbon potential of source rocks, thermal maturity history, and timing of hydrocarbon generation. The potential shale gas interval is buried to $5000-6000 \mathrm{~m}$ and has a temperature of $225-270^{\circ} \mathrm{C}$. To summarize, the calcareous part of the Endröd Formation can be considered a fair quality, gas-prone source rock [24]. The largest oil and gas field in Hungary, the Algyö Field, is situated southwest of the Makó Trough [40, 48] and was sourced from there. The Endröd Formation has also been assumed to be a potential basin-centered gas accumulation (cf. Law 2002 [19]) which is an unconventional gas accumulation with tight sandstone reservoirs of the regional extent but very low porosity and permeability.

\section{Materials and Methods}

In this study, three Upper Miocene lacustrine formations were sampled: the Endrőd, Szolnok, and Algyő Formations. Samples were taken from core sections of six wells located in different locations and depth intervals within the same subbasin (Figure 4). For wells proprietary to the TXM Ltd. Company, a code system will be used throughout the text. Two wells (M6, M7) are located in the deepest and central part of the Makó Trough. Four wells (Sz1, K1, Mcs1, B1) are located on the flanks. Fifteen core intervals from six wells were sampled over a depth interval from 2702 to $5475 \mathrm{~m}$ (Figure 4 and Table 1). This study focused on sandstones, but samples of finer grained deposits were also examined (Table 1). The analyzed deposits are comprised of sandstones, calcareous marls, and siltstones that were selected 


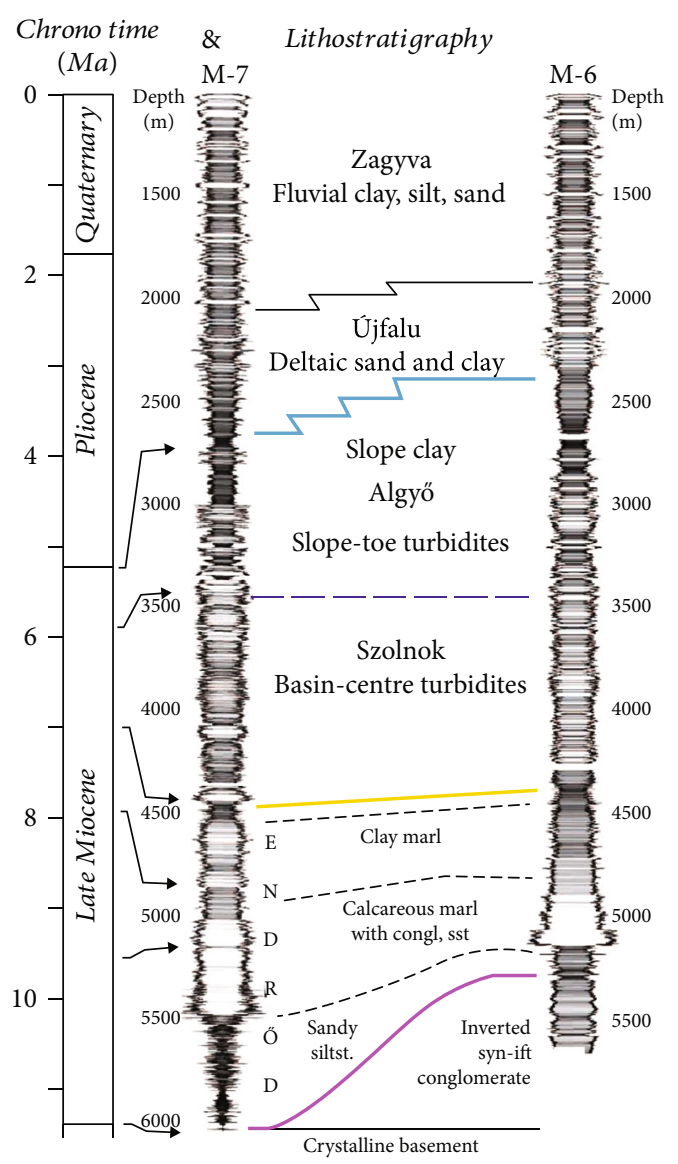

FIGURE 3: Chrono- and lithostratigraphy of the sedimentary rocks in the Makó Trough. The lithology is indicated by mirrored gamma logs $[25,35]$.

from the middle and upper part of the open-water marl formation (Endrőd Fm), the basin-centre turbidite system (confined turbidite; Szolnok Fm), and unconfined turbidite system (lower unit of Algyő Fm).

Thin sections were analyzed $(55,75$, and 30 each from the Endrőd, Szolnok, and Algyő Formations, respectively) with an OLYMPUS BX41 optical microscope. All the samples were impregnated with blue resin before thin sectioning in order to facilitate porosity identification. Staining with Alizarin Red S and K-ferricyanide [49] was applied to all of the thin sections in order to distinguish carbonate minerals and their respective iron content. Additionally, 10 samples were stained with a potassium rhodizonate solution to distinguish plagioclase and a sodium cobaltinitrite solution to distinguish K-feldspar. Point counting was performed on 27 samples to investigate quantitative composition; 300 points per thin section were counted. From each analyzed core interval, representative samples were selected by visual inspection.

A microscope equipped with a $\mathrm{Hg}$ vapour lamp and filters for blue light excitation (450-490 nm) was used to detect the organic matter. The filter set was composed of a diachromatic beam splitter $(510 \mathrm{~nm})$ and a barrier filter $(515 \mathrm{~nm})$. Cathodoluminescence (CL) study was performed on polished thin sections using a MAAS-Nuclide ELM-3 cold- cathode CL device operating at $10 \mathrm{kV}$ (Measurement and Analysis Systems, Inc., Lowell, MA, USA).

An Amray 1830i type Scanning Electron Microscope equipped with an INCA Energy-dispersive X-ray spectrometer was used in the secondary electron (SE), backscatter electron (BSE), and cathodoluminescent (CL) modes on polished thin sections. A total of 21 samples were analyzed. Surfaces, coated with gold, were studied on a FEI Inspect S Scanning Electron Microscope. The chemical composition of minerals was determined by a JXA-8530F type Electron Probe Microanalyzer in WDS mode. Measurement conditions were accelerating voltage of $15 \mathrm{kV}$, probe current $20 \mathrm{nA}$, beam diameter 5-10 $\mu \mathrm{m}$, and ZAF correction. Altogether, 20 samples were analyzed. Fractured surfaces of eight samples, coated with gold, were studied on a FEI Inspect S Scanning Electron Microscope.

X-ray diffraction was used for the identification of the mineralogical composition of separated clay fractions. The samples were analyzed with a Panalytical PW 3040/60 X'Pert PRO diffractometer (CuK $\alpha$ radiation, $40 \mathrm{kV}, 40 \mathrm{~mA}$, step size $0.0167 \mathrm{~s}$ per step).

For clay mineral analysis, the $<2 \mu \mathrm{m}$ fraction samples were separated from the sandstones [50]. Fifteen samples were analyzed (Table 1). Sandstones were crushed with a hammer, then disaggregated with diluted $\mathrm{H}_{2} \mathrm{O}_{2}$ and treated with a $400 \mathrm{~W}$ ultrasonic probe (2-3 min). Samples containing carbonate were treated with $0.1 \mathrm{M}$ EDTA solution ( $\mathrm{pH} 4.5$ ) and washed with distilled water [51]. Size fractionation was accomplished by timed sedimentation (Stokes'size fraction). Oriented XRD mounts were prepared by pipetting the suspensions ( $7 \mathrm{mg}$ sample in $1 \mathrm{ml}$ of distilled water) onto glass slides and analyzed after air drying. Furthermore, the clay fractions were saturated with $\mathrm{K}^{+}$or $\mathrm{Mg}^{2+}$ ions, followed by ethylene glycol or glycerol saturation or heating $\left(550^{\circ} \mathrm{C}\right)$, in order to identify expandable or heat-sensitive clay minerals [50]. The clay fractions were additionally saturated with DMSO (dimethyl sulphoxide) in order to identify kaolinite in the presence of chlorite [52]. Chlorite does not swell with DMSO, so peaks remain unchanged after treatment. In the case of kaolinite, the $7.15 \AA$ peak moves to the $11.2 \AA$ position.

The $<0.2 \mu \mathrm{m}$ fraction samples were separated by timed centrifugation from eight samples (Table 1). The resulting suspensions were concentrated by evaporation, and the wet samples were freeze-dried. Oriented preparations for XRD were made by dispersing ca $5 \mathrm{mg}$ clay separate in $1 \mathrm{ml}$ of water, pipetting the suspension onto a glass slide and drying at room temperature. Oriented XRD mounts were solvated with ethylene glycol at $60^{\circ} \mathrm{C}$ for $12 \mathrm{~h}$. In mixed-layer phases, the percentage of illite was determined by the $2 \Theta$ difference values of the peak positions $001 / 002$ and $002 / 003$ of the illite/smectite mixed-layer peaks [50].

The clay minerals were quantified with a modified version of the Schultz method [53]. The peak areas of the clay minerals in the $\mathrm{Mg}$ and glycerol saturated X-ray patterns were determined using the Panalytical X'Pert Highscore plus software. The correction factors of Schultz [53] which were originally used for the quantification of clay minerals in bulk samples were used to quantify the clay fraction. The 


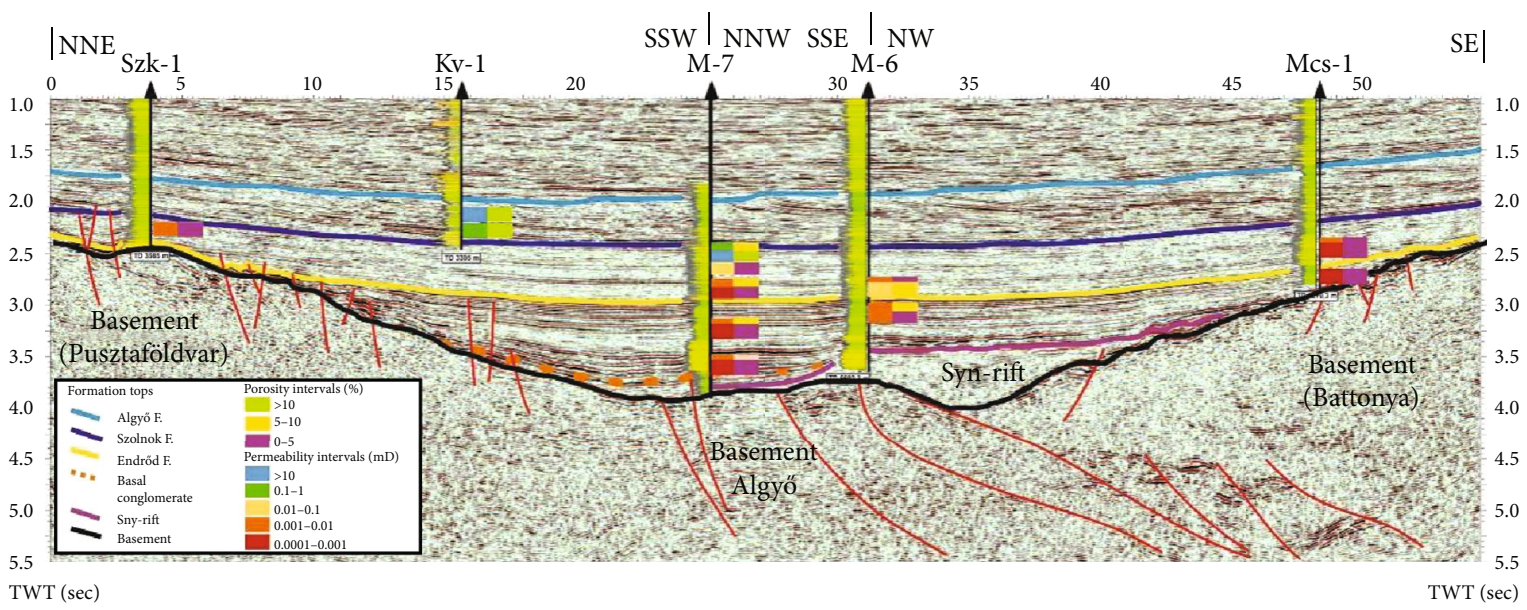

Figure 4: Seismic section of studied wells and core intervals (colored and empty squares) [41] along the line shown in Figure 1. Porosity and permeability ranges were measured on core samples from the Makó Trough (TXM interim report).

TABLE 1: Distribution of studied samples within the formations.

\begin{tabular}{|c|c|c|c|c|c|c|c|c|}
\hline \multirow[b]{2}{*}{ Formation } & \multirow[b]{2}{*}{ Well } & \multirow[b]{2}{*}{$\begin{array}{c}\text { Core } \\
\text { number }\end{array}$} & \multirow{2}{*}{$\begin{array}{c}\text { Core } \\
\text { thickness (m) }\end{array}$} & \multirow{2}{*}{$\begin{array}{l}\text { Number of thin } \\
\text { sections }\end{array}$} & \multicolumn{3}{|c|}{ Number of samples } & \multirow{2}{*}{$\begin{array}{l}\text { Number of clay mineral } \\
\text { samples }\end{array}$} \\
\hline & & & & & Sandstones* & $\begin{array}{l}\text { Claystones and } \\
\text { siltstones }\end{array}$ & $\begin{array}{l}\text { Calcareous } \\
\text { marls }\end{array}$ & \\
\hline Algyő & K1 & $\mathrm{c} 1, \mathrm{c} 2$ & 29.9 & 14 & 11 & 3 & & 8 \\
\hline Algyő & B1 & $\mathrm{cl}$ & 45.7 & 16 & 9 & 5 & & \\
\hline Szolnok & Szk1 & $\mathrm{c} 1$ & 8 & 14 & 9 & 5 & & \\
\hline Szolnok & M7 & $\begin{array}{l}\mathrm{c} 1, \mathrm{c} 2, \mathrm{c} 3 \\
\mathrm{c} 4\end{array}$ & 36.8 & 31 & 22 & 9 & & 7 \\
\hline Szolnok & M6 & $\mathrm{cl}$ & 9 & 14 & 10 & 4 & & \\
\hline Szolnok & Mcs1 & $\mathrm{c} 1$ & 9 & 16 & 10 & 6 & & \\
\hline Endrőd & M7 & c5, c6 & 18 & 18 & 12 & & 6 & 4 \\
\hline Endrőd & M6 & $c 2, c 3$ & 15 & 18 & 12 & & 6 & \\
\hline Endrőd & $\mathrm{c} 2$ & 6 & 19 & 14 & & 5 & & \\
\hline
\end{tabular}

${ }^{*}$ Studied in detail.

correction factors are 0.35 for smectite, 0.54 for chlorite, 1 for illite, and 0.5 for kaolinite.

Polished sections of $1 \mathrm{~cm}$ thickness were prepared for sampling the calcite under a binocular microscope. A computer-controlled micromill was used to separate carbonate phases. Stable carbon and oxygen isotope analyses were carried out on 35 samples with a MAT253 gas isotope mass spectrometer (Thermo Scientific) coupled to a Kiel IV (Thermo Scientific) automatic preparation line. The carbonates were digested in $\mathrm{H}_{3} \mathrm{PO}_{4}$ at $70^{\circ} \mathrm{C}$ in a vacuum following the method of McCrea [54]. The results are expressed in $\delta$ -notation on the Vienna PDB standard.

\section{Results}

\subsection{Sandstone Petrography}

4.1.1. Detrital Grains. Textural features within the sandstones exhibit a well-defined trend from bottom to top. Both sorting and maturity gradually increase upward. Sandstone interbeds of the Endröd Formation are characterized by very fine to fine-grained sandstones. The grains are poorly to moderately sorted and angular to subrounded. The matrix is abundant among the detrital grains. The maturity stage sensu Folk [55] varies between immature and submature. The Szolnok Formation comprises predominantly fine to mediumgrained sandstones, which locally alternate with thin layers of siltstones. Grains are moderately sorted and angular to subrounded. Its maturity stage sensu Folk [56] is classified as submature. The Algyö Formation consists of fine to medium-grained sandstones, which alternate with siltstone lamina. Grains are angular to subrounded and moderately to well sorted. The maturity stage sensu Folk [56] is classified as submature to mature.

Detrital grains in all three formations consist of quartz, feldspar, mica, sedimentary, and metamorphic rock fragments. Monocrystalline and polycrystalline quartz are the most abundant detrital mineral in all three formations. Kfeldspar of pale blue to grey luminescent color was found in the uppermost part of the Endröd and in the Algyö 


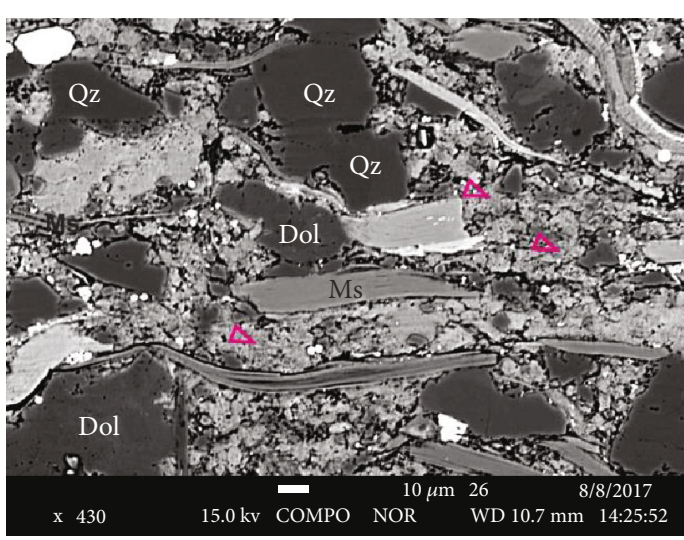

(a)

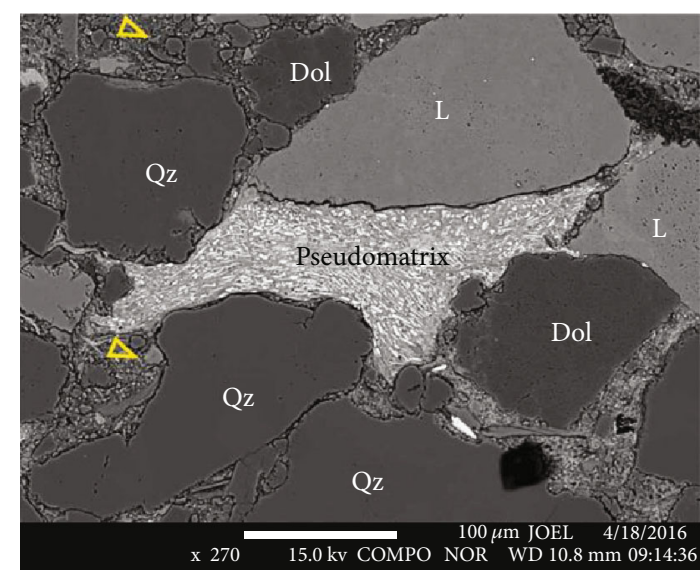

(b)

FIgURE 5: SEM-BSE images showing sedimentary components in matrix-rich sandstones. (a) Calcite matrix (pink arrows) occurs only in the sandstones of the Endrőd Formation, well M7, 5471 m, Endrőd Fm. (b) Pseudomatrix and siliciclastic matrix (yellow arrows) among detrital grains in sandstones of the lower turbidite system, well M7, 3410 m, Szolnok Fm. Abbreviations: L: carbonate rock fragment; Dol: dolomite; Ms: muscovite; Qz: quartz.

Formation. Plagioclase feldspar with a luminescence varying between green to none is present in all formations. Mica exists as muscovite and biotite and is the most abundant in the Endröd Formation. Metamorphic rock fragments consist of chloritic and muscovitic schists.

Sedimentary rock fragments are comprised of dolomites and crystalline limestones. Many detrital calcite grains stain pink. Angular detrital dolomite grains are common in the Endröd Formation. These grains consist of a cluster of crystals, which include euhedral and/or subhedral dolomite core and a thin ankerite outer growth band. The crystal aggregates, i.e., the sedimentary grains themselves, possess an angular and corroded outer surface, whereas the individual crystals commonly have planar face inside the clusters. In the marginal zone of the grains, euhedral dolomite rhombs are truncated together with the ankerite outer zone. In the Szolnok and Algyö Formations, the dolomite rock fragments occur as rounded, sand-sized grains. In a few samples, partly calcitised, finely crystalline dolomite grains were encountered. Bioclasts having recognizable shape are rare in the sandstones.

4.1.2. Matrix. The matrix is composed of silt and clay-sized detrital grains such as quartz, calcite, mica, dolomite, and clay minerals such as chlorite, illite, and mixed-layer clays. Sandstones of the Endröd Formation are matrix-rich. In the middle unit of this formation, the matrix predominantly consists of calcite (Figure 5(a)), whereas in the upper unit of this formation, it is composed of siliciclastic particles. In the Szolnok and Algyő Formations, matrix is less common; it mainly occurs as pseudomatrix (Figure 5(b)) or as intergranular matrix in some samples. It is composed of calcite, dolomite, quartz, muscovite, and chlorite.

4.1.3. Grain Contacts. In the studied sandstones, both point, linear, and concavo-convex grain contacts were observed (Figures 6(a)-6(c)). Point contacts occurring together with linear contacts are very rare. They are only encountered in a few samples from the middle part of the Endröd Formation. Otherwise, linear and concavo-convex contacts are typical among framework grains in the upper part of the Endröd Formation. Elongated detrital grains, especially mica, are oriented parallel to bedding or are slightly deformed. In the Szolnok and Algyő Formations, linear and concavo-convex contacts are characterized among framework grains; otherwise, clay-rich lithoclasts and mica are deformed. Between rigid grains, like quartz, pressure dissolution surfaces also occur, especially in the Algyő Formation.

4.1.4. Diagenetic Minerals. The following diagenetic minerals were identified: albite, quartz, ankerite, calcite, pyrite, and clay minerals (Figure 6). Almost all diagenetic components were observed in all three formations; however, there are some components that are specific to only one formation. Ubiquitous clay coats on grain surfaces were only observed in a few samples of the Szolnok and Algyö Formations. However, in the majority of samples, they are scarce or absent. The coats are composed of mixed-layer illite/smectite or chlorite and commonly completely cover detrital grains. In the Endröd Formation, albite of the fine sand size of the euhedral shape indicates an advanced replacement process and additional cement precipitation. Diagenetic albite is nonluminescent. In the Szolnok and Algyö Formations, diagenetic albite occurs inside the detrital K-feldspar and plagioclase grains, indicating a replacement process (Figures 6(c) and 6(d)). K-feldspar and plagioclase grains commonly contain secondary intragranular pores and/or are partially replaced by calcite or kaolinite and dickite in the uppermost part of the Szolnok and the entire Algyö Formation (Figures 6(b)-6(e)). Syntaxial overgrowth quartz cement is abundant in the Algyö Formation and scarce in the other formations (Figure 6(f)). Microcrystalline quartz cement commonly forms intergrowth with diagenetic clay minerals, such as chlorite and illite, and it occurs in all formations. 


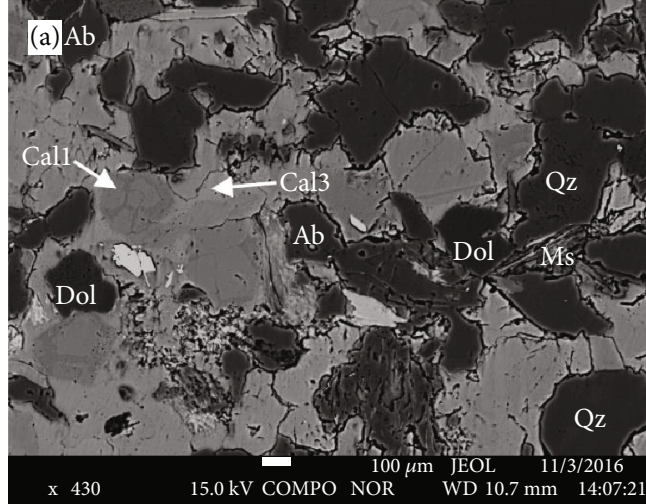

(a)

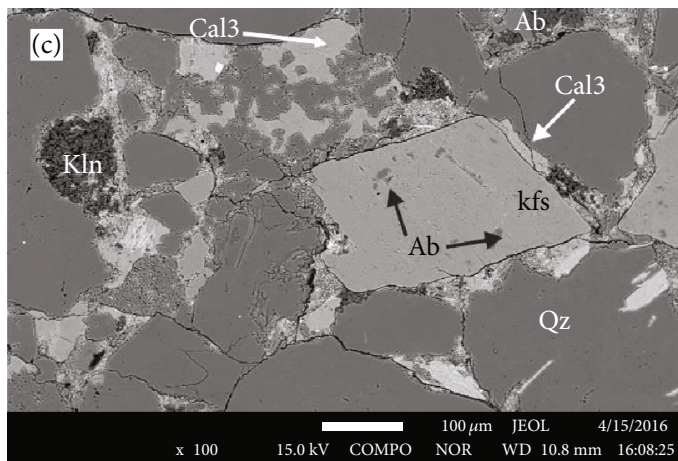

(c)

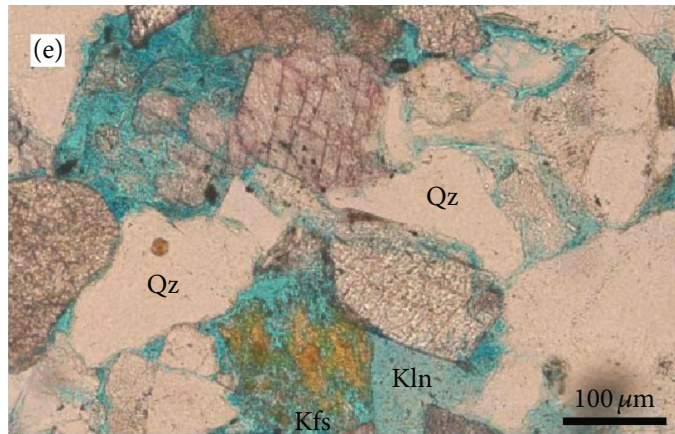

(e)

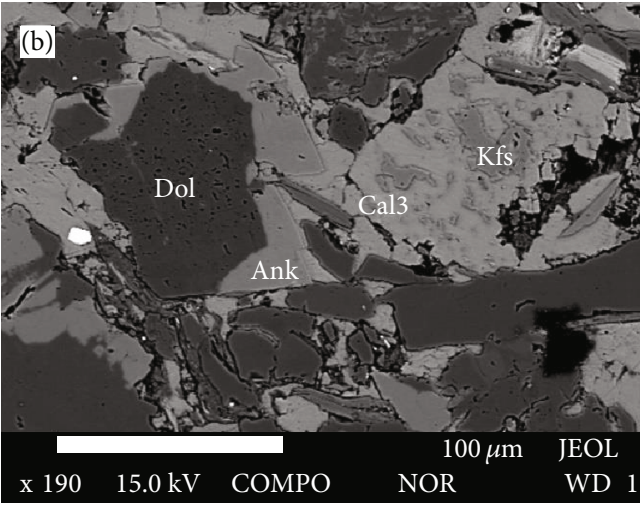

(b)

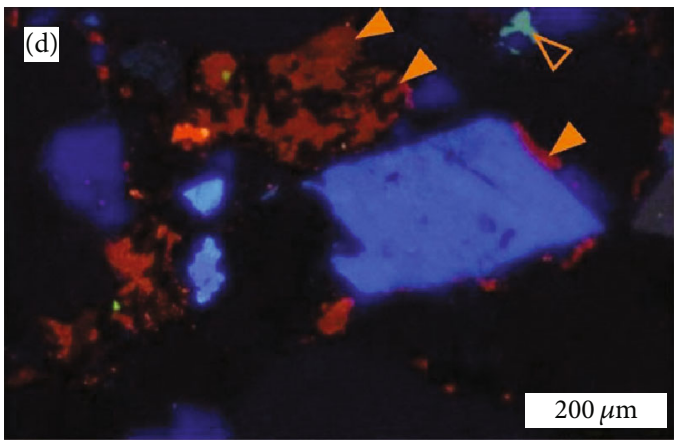

(d)

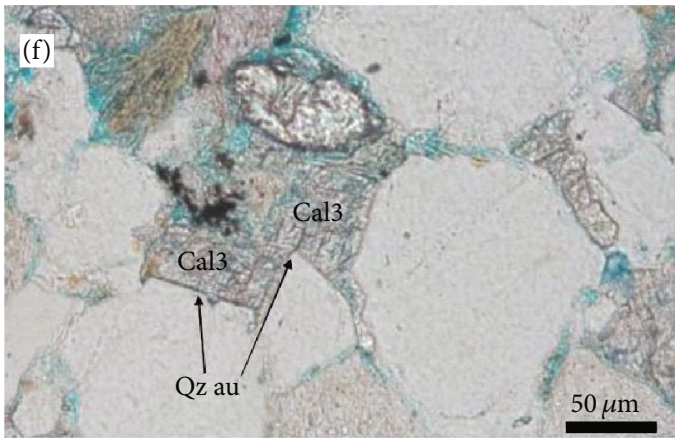

(f)

FIGURE 6: SEM-BSE images, photomicrographs, and CL image showing diagenetic components.(a) Fine-grained sandstones are characterized by concavo-convex grain contacts. Calcite (Cal1) crystals exhibit a faint crosspattern that resembles coccolith morphology. Large mottles of calcite (Cal3) include replacive and cement phases. Microcrystalline quartz cement occurs on quartz grains, well Mcs1, 4060 m, Endröd Fm. (b) Ankerite cement crystals on dolomite grain. Replacive calcite (Cal3) includes the small remnants of detrital K-feldspar, well M7, 4103 m, Szolnok Fm. (c) Sandstones of the Szolnok Formation are characterized by linear grain contacts. Diagenetic minerals consist of replacive and cement calcite (Cal3), albite and kaolinite, well M7, 3410 m, Szolnok Fm. (d) CL image of the field of view shown in (c). Detrital K-feldspar of pale blue luminescent includes nonluminescent diagenetic albite. Detrital albite of greenish blue fluorescent color (empty arrow) is present among kaolinite. Postcompactional calcite (Cal3) exhibits dull red luminescent color (filled arrows), well M7, 3410 m, Szolnok Fm. (e) Vuggy porosity (blue resin) includes secondary intragranular pores, which are typical in calcite (stained pink) and K-feldspar (stained yellow) and secondary, dissolution-enlarged intergranular pores, which are characterized between framework grains. Kaolinite occurs next to K-feldspar, well K1, 3020 m, Algyő Fm. (f) Quartz with straight crystal face indicates authigenic overgrowth cement precipitation. Postcompactional calcite (Cal3) engulfs quartz cement, well K1, 3036 m, Algyő Fm. Abbreviations: Ab: albite; Ank: ankerite; Cal: calcite; Dol: dolomite; KFs: K-feldspar; Kln: kaolinite; Ms: muscovite; Qz: quartz; Qz au: authigenic quartz. (a)-(c) SEM-BSE images. (d) Cathodoluminescent image. (e, f) Plane polarized light.

Framboidal pyrite was encountered in the matrix in all the three formations - it is very common in the Endröd Formation and rare in the Szolnok and Algyő Formations. Additionally, cubic crystals of several tens of micrometers in size are scattered in matrix-rich sandstones of the Endröd Formation. Fine crystals and crystal aggregates of pyrite abundantly occur next to secondary pores in the Algyö Formation. Quite often, authigenic ankerite entirely or partly replaces the 


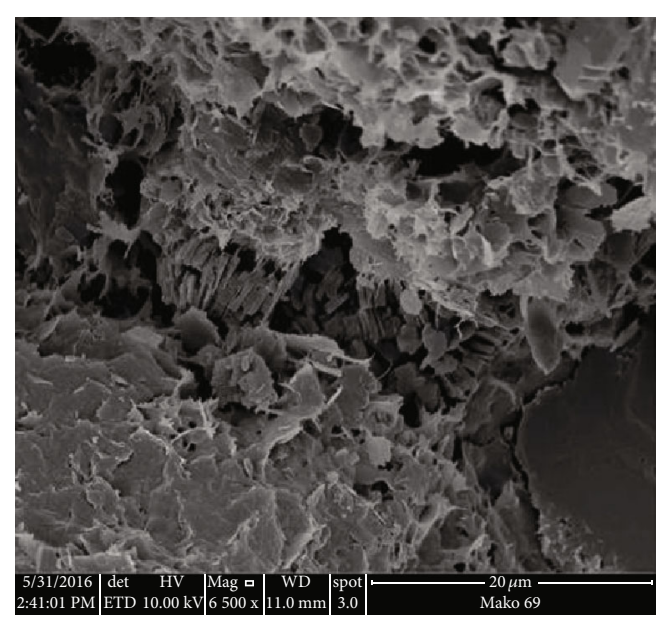

(a)

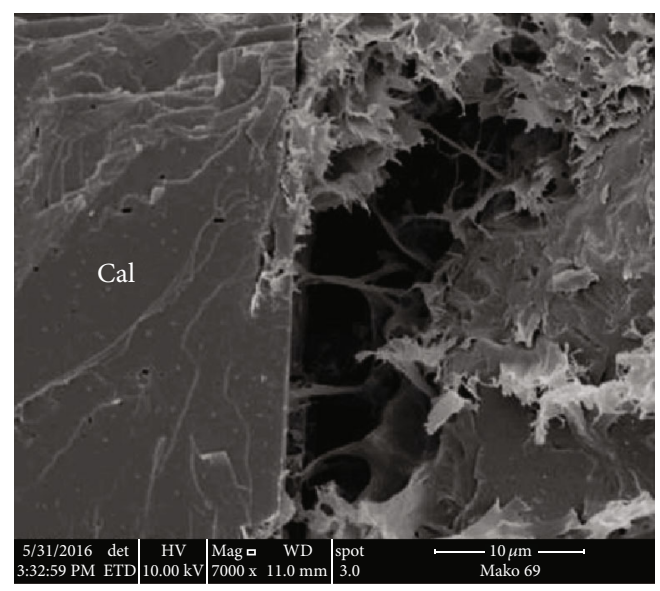

(c)

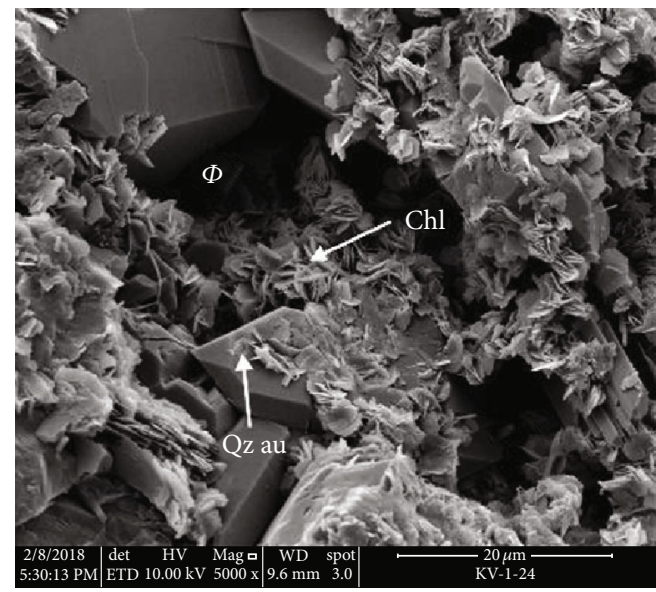

(e)

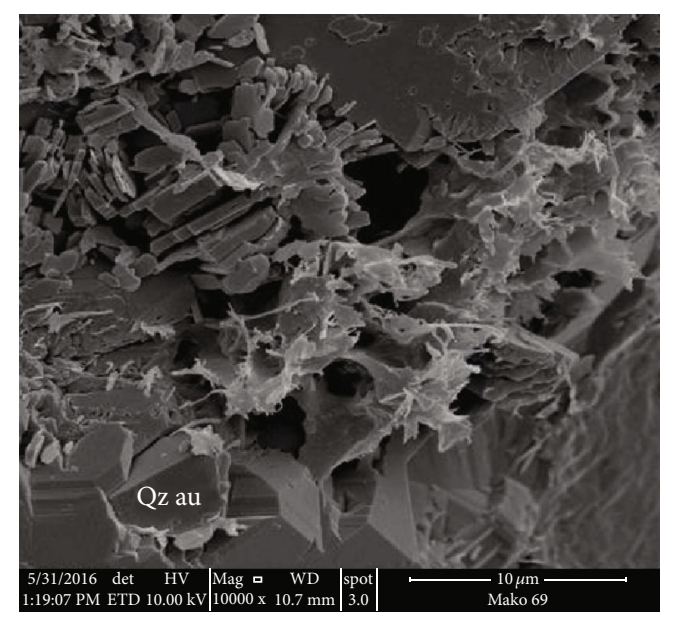

(b)

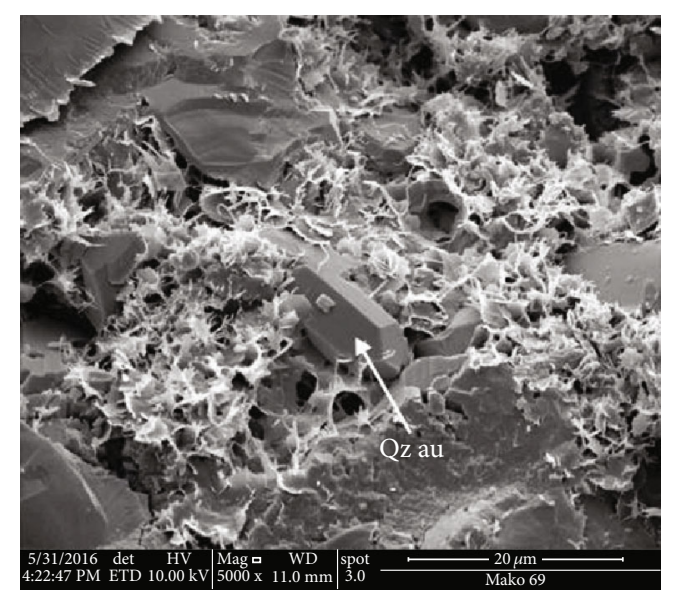

(d)

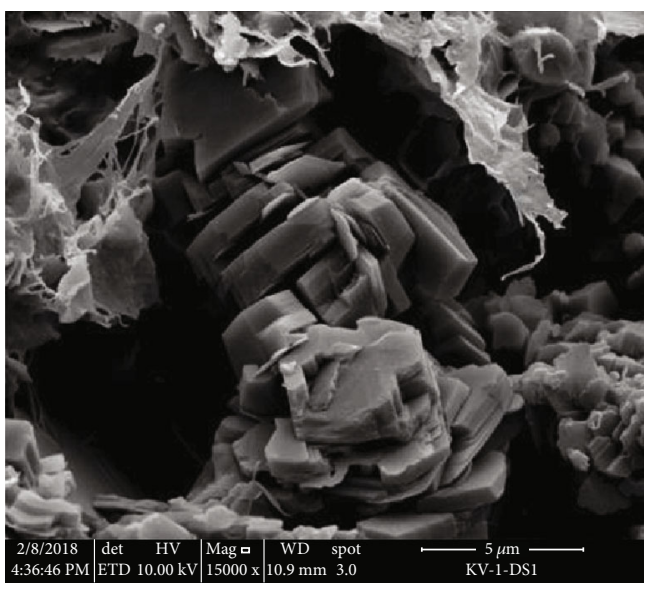

(f)

FIGURE 7: SEM-SE images showing the features of diagenetic clay minerals. (a) Kaolinite occurs together with mixed-layer illite/smectite, well M7, 3421 m, Szolnok Fm. (b) Kaolinite and authigenic microcrystalline quartz, well M7, 3421 m, Szolnok Fm. (c) Pore-bridging illite, well M7, 3421 m, Szolnok Fm. (d) Mixed-layer illite/smectite forms intergrowths with diagenetic quartz, well M7, 3412 m, Szolnok Fm. (e) Pore-filling and grain-rimming chlorite locally forming intergrowths with authigenic quartz, well K1, 3023 m, Algyő Fm. (f) Thick layers of kaolinite/dickite with mixed-layer illite/smectite, well K1, 3012 m, Algyő Fm. Abbreviations: Cal: calcite; Qz au: authigenic quartz; Chl: chlorite.

detrital dolomite grains in the form of irregular alteration rims (Figure 6(b)). Additionally, subhedral ankerite crystals possessing planar crystal faces are attached to dolomite grains. These cement crystals engulf the linear contacts of the framework grains and occlude primary intergranular pores. Altogether, authigenic ankerite crystals are thicker 


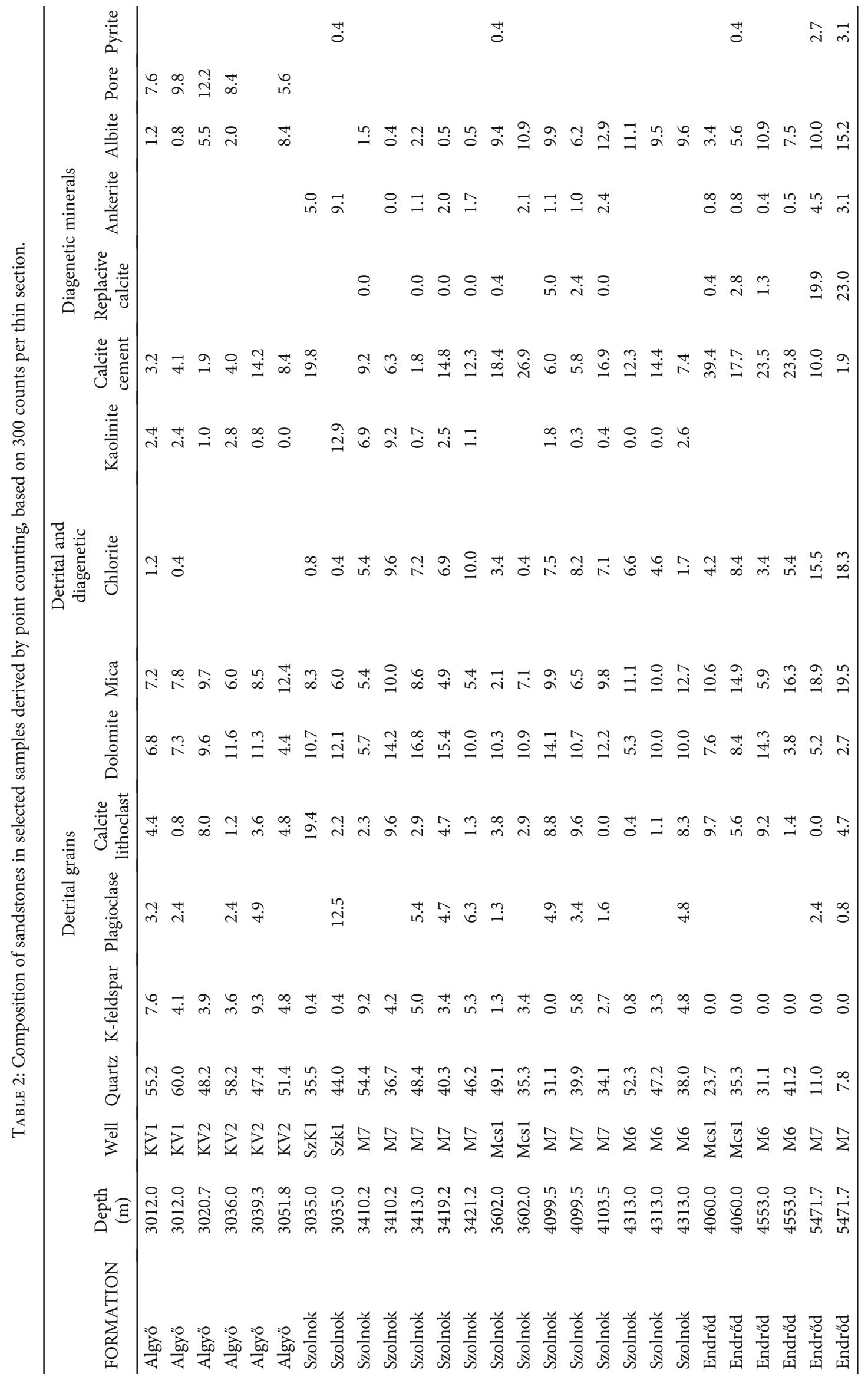




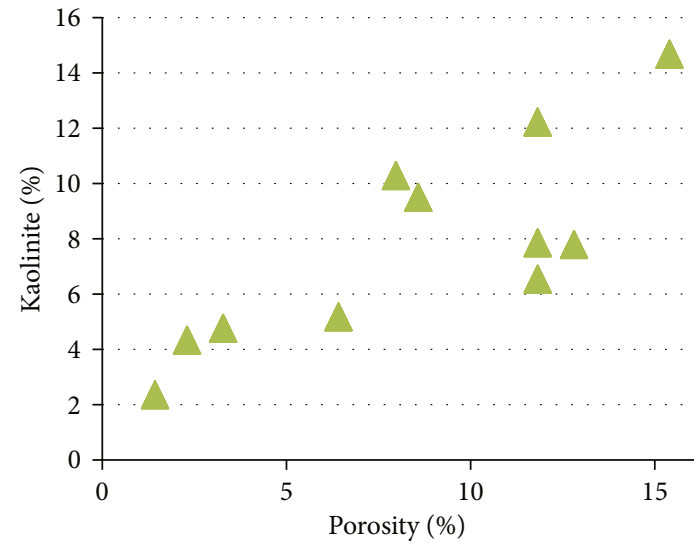

Figure 8: Linear correlation between the kaolinite content and porosity, in the upper turbidite sandstones (Algyő Formation).

and larger in size than those inherited in detrital grains composing crystal aggregates together with dolomite crystals. In addition, in the Szolnok Formation, Fe-rich alteration rims can be detected in many rounded, detrital dolomite grains and are typified by the irregular boundary line. Both dolomite grains and ankerite crystals are commonly replaced by calcite. In the Algyő Formation, ankerite crystals are characterized by both planar faces and serrated surfaces. The latter is observed along secondary pores.

Calcite occurs as pre and postcompactional cement crystals, and the former comes in two types. In the Endröd and Szolnok Formations, finely crystalline euhedral to anhedral displacive calcite (Cal1) is typified by sector and/or normal zonation as well as pink staining (Figure 6(a)). Many crystals are surrounded by curved mica plates. Additionally, matrix grains show a curved arrangement above and below these crystals, especially in the matrix-rich sandstones of the Endröd Formation. Very thin calcite cement (Cal2), occurring as a film, covers the detrital grains, where point contacts of the grains occur. In the areas surrounding the mottles, the grains have linear contacts. Overall, this is rather rare, as it was only encountered in a few sandstone interlayers, within calcareous marls in the middle part of the formation. The calcite (Cal2) exhibits bright orange luminescent color under CL. Poreoccluding calcite crystals (Cal3) occur in all the three formations. They are stained blue to mauve-indicating that this phase is ferroan. Crystals engulf linear and concavo-convex grain contacts (Figures 6(b)-6(d)). They have a compromise boundary with the overgrowth quartz cement in the Algyo" Formation (Figure 6(f)). The replacive phase of calcite (Cal3) occurs as irregular mottles among the detrital grains, and crystals include small remnants of precursor feldspars, dolomite, and ankerite. These remnants have corroded boundaries toward the calcite (Figures 6(b)-6(d)). Elementary maps and SEM and CL images revealed that coarser calcite (Cal3) crystals nucleated as a replacive phase on precursor sedimentary grains (K-feldspar, carbonates, dolomites, and metamorphic rock fragments) or diagenetic crystals (ankerite and calcite) and enlarged as cement occluding the reduced primary intergranular pore space (Figures $6(\mathrm{~b})-6(\mathrm{~d})$ ). Finely crystalline calcite (Cal3) is commonly a pore-occluding cement phase (Figure 6(d)).

Mixed-layer illite/smectite is present as grain coatings in a few samples and as a pore-filling mineral in the Szolnok Formation (Figures 7(a)-7(d)). It is rare in the Algyő Formation. Discrete illite appears as a pore-bridging mineral (Figure $7(\mathrm{c})$ ). Chlorite and mixed-layer clays commonly form intergrowths with microcrystalline quartz cement (Figures 7(b) and 7(d)). In a few samples of the Algyö Formation, chlorite is the predominant cement phase, occurring as both a grain coating and a pore-occluding mineral (Figure $7(\mathrm{e})$ ). Blocky and vermicular kaolinite and dickite occur along partially dissolved feldspar grains, or in intergranular pores reduced by compaction (Figures $7(a), 7(b)$, and $7(\mathrm{f}))$. The thickness of the blocky crystals can achieve ca $1.3 \mu \mathrm{m}$ (in the Szolnok Formation) and ca $3.1 \mu \mathrm{m}$ (in the Algyö Formation). Kaolinite engulfs quartz overgrowth cement.

4.1.5. Porosity. In the Endröd and Szolnok Formations, no porosity sensu Rouquerol [57] could be detected under optical microscope. However, microporosity in sandstones associated with diagenetic clay minerals, such as illite, kaolinite, and chlorite, was observed via SEM analysis (Figure 7). Micropores are smaller than $20 \mu \mathrm{m}$ and are remnants of the primary pore space that was reduced by compaction and various cements, such as quartz, calcite, and clay minerals (Figure 7). In samples of the Szolnok and Algyö Formations, where diagenetic chlorite cement is present, calcite (Cal3) cement is commonly missing and micropores appear.

In the uppermost part of the Szolnok Formation and the Algyő Formation, secondary macroporosity is present up to $12.3 \%$ (Table 2). The most characteristic secondary pore type is vuggy, which mainly appears as dissolution-enlarged intergranular voids. The secondary pores have a highly irregular shape as both the margins of the sedimentary grains and that of the diagenetic crystals which are dissolved. Their size is commonly smaller than $100 \mu \mathrm{m}$. Intracrystalline secondary porosity was detected inside the postcompactional diagenetic calcite. Intragranular secondary pores occur in unstable detrital K-feldspar and calcite grains (Figure 8). An uneven, rough surface of diagenetic ankerite is also characterized along these secondary pores. Microporosity among kaolinite/dickite crystals is also typical. These micropores are either remnants of primary porosity reduced by compaction and cementation, or remnants of secondary dissolutional intragranular pores within K-feldspars, which was filled by kaolinite. The open pores are interconnected.

Based on petrographic features, the analyzed sandstones can be classified into three lithofacies, dominated by secondary porosity, matrix, and carbonate cement (Figure 9). In the majority of the samples, the intergranular area is dominated by matrix and diagenetic calcite, resulting in low porosity and permeability values. Porous sandstones, characterized by high porosity and permeability values, are widespread in the Algyö Formation and in the upper part of the Szolnok Formation.

4.1.6. Other Characteristic Features. Under optical microscope, dissected brown streaks of organic matter typically 

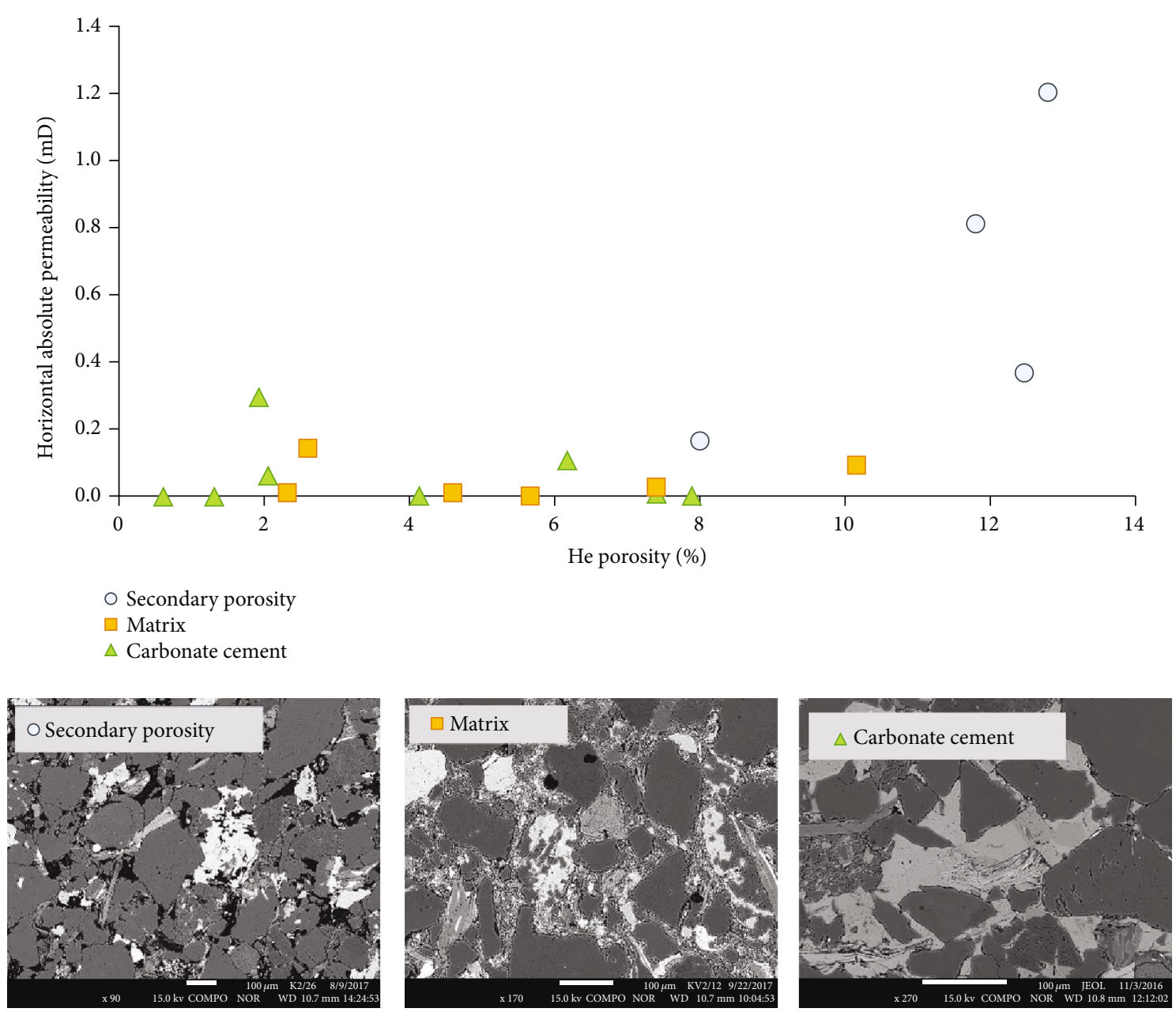

FIgURE 9: Classification of samples into three rock types in the analyzed sandstones. Relation of porosity and permeability and SEM images.

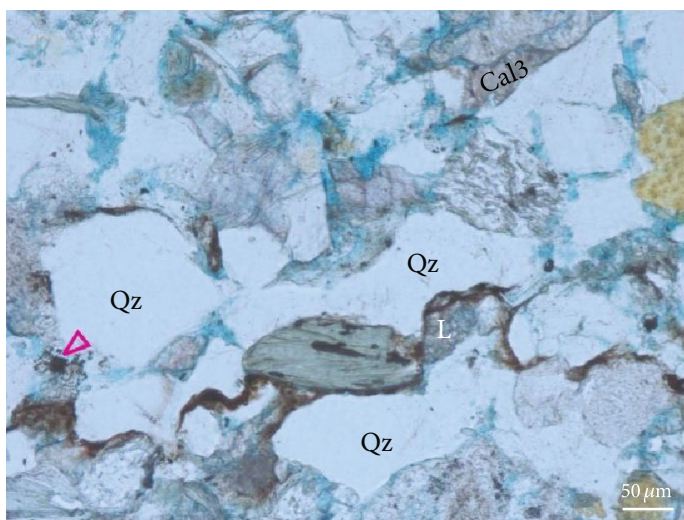

(a)

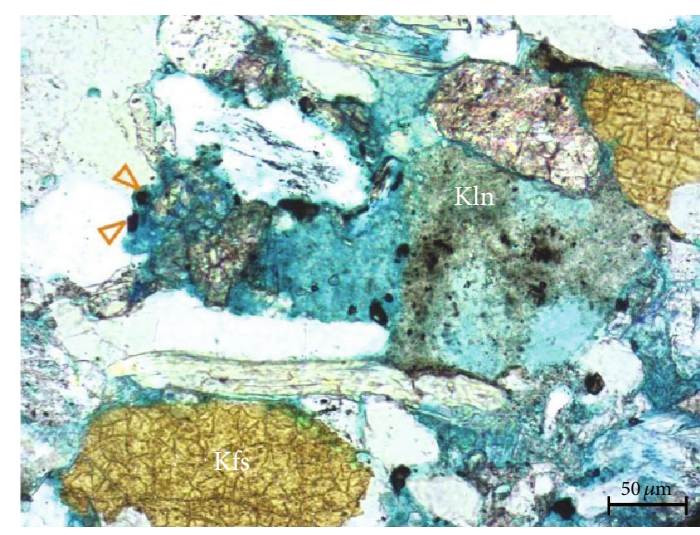

(b)

FIGURE 10: Photomicrographs showing petrographic features of the bituminous organic matter in samples of the Algyő Formation. (a) Brown streaks of organic matter occur along concavo-convex grain contacts. Along secondary pores (blue resin), dark dots include pyrite and organic matter (open arrows), well K1, $3051 \mathrm{~m}$, Algyő Fm. (b) Pyrite together with organic matter (open arrows) occurs along secondary pores and among kaolinite crystals, well B1, 2702 m, Algyő Fm. Abbreviations: Cal: calcite; Kln: kaolinite; Kfs: K-feldspar; L: carbonate rock fragment; Qz: quartz. (a, b) plane polarized light. 


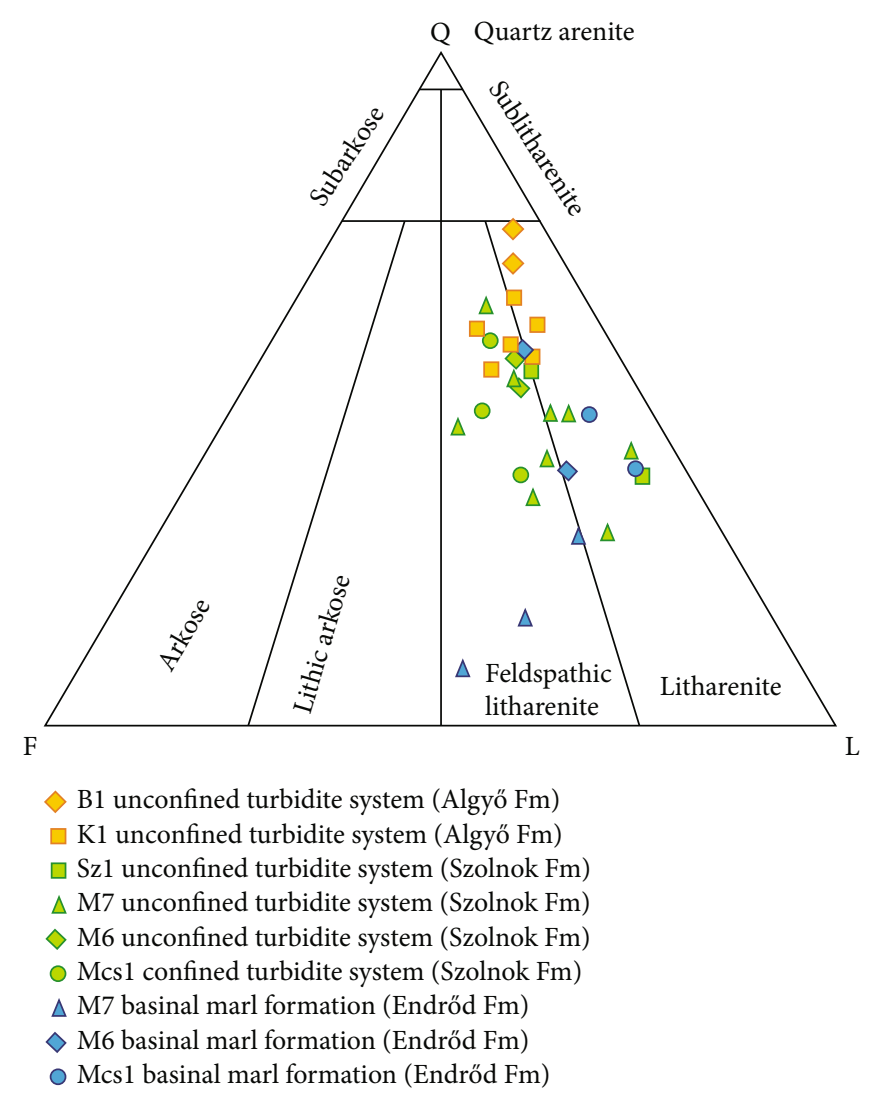

FIgURE 11: QFL classification of sandstones (after Folk [56]).

occur along concavo-convex grain contacts and pressure dissolution surfaces in the Algyő Formation (Figure 10(a)). The streaks bifurcate and surround the framework grains. The brownish color is unevenly darker and lighter along the streaks, and their thickness varies slightly. The surface of postcompactional calcite cement crystals (Cal3) is corroded along the contact with the brownish organic matter. Brown dots of organic matter occasionally fill in the tiny secondary pores of calcite cement crystals and feldspar grains. No brownish solid organic matter was detected on open pore walls. Small dots of the brownish organic matter (Figure 10(b)), which are often associated with pyrite crystals, exhibit bright green fluorescence under blue light. The brownish streaks of organic matter themselves are not fluorescent. Mottles of microporous kaolinite occasionally include brownish dots, as well (Figure 10(b)). Based on petrographic features and relationships with other components, the organic matter was identified as solid bituminous residue of migrated hydrocarbons [58, 59].

4.2. Quantitative Composition. The analyzed sandstones are litharenites and feldspathic litharenites (cf. Folk [56]; Figure 11, Table 2). The proportion of detrital grains varies in the studied formations. The amount of detrital quartz in sandstones gradually increases upward from the Endröd Formation to the Algyö Formations, whereas the amount of mica and chlorite decreases. The quartz content is higher in the Algyö Formation (47-60\%) and lower in the Szolnok
(15-54\%) and Endrőd Formations (8-41\%). The proportion of detrital feldspar decreases from 14 to $0.4 \%$ with depth. The K-feldspar content is higher in the Algyő Formation (3-9\%) and gradually decreases with burial depth from the Szolnok Formation (0-9\%) to the Endröd Formation (0-0.4\%). The dolomite clast content is rather variable: $3-14 \%$ in the Endröd Formation, $2-17 \%$ in the Szolnok Formation, and 4$11 \%$ in the Algyö Formation. The proportion of diagenetic albite (from 0.4 to $15 \%$ ) and ankerite (from 1 to $4 \%$ ) gradually increases with depth.

In the Szolnok Formation, a lateral variation of quantitative composition within the calcite-cemented intervals can be seen. The amount of diagenetic calcite increases from the centre of the basin toward the margin (from 2 to 27\%). The same trend is seen in the Endröd Formation in the southeastern part of the basin. The highest porosity and permeability values can be found in the Algyö Formation and in the uppermost part of the Szolnok Formation. For the other parts of the basin, very low values are characterized.

4.3. Clay Mineralogy. Typical clay mineral phases are illite, chlorite, mixed-layer illite/smectite (I/S), and kaolinite (Figure 12). Based on the results of the XRD analysis of clay fractions, the measured proportions of illite and chlorite are similar; they range between $11.9-64.5 \%$ and $11.2-57.7 \%$, respectively. The proportion of mixed-layer clays is a bit less, varying from 7.6 to $53.6 \%$. The amount of kaolinite is even less; it varies between 2.3 and $14.7 \%$. Since high amount of kaolinite and chlorite is connected to distinct layers of the sandstone, no depth-related trend could be recognised in the amount of clay minerals.

Kaolinite, confirmed by DMSO, is present in varying quantities in the Algyő Formation. Its amount decreases in the uppermost part of the Szolnok Formation, whereas it was not detected in the lower part of this formation or in the Endröd Formation.

Illite, chlorite, kaolinite, and mixed-layer illite/smectite (I/S) are typical in the $<0.2 \mu \mathrm{m}$ fraction. The reflection at $27 \AA$ indicates $\mathrm{R} 1$ ordering of the I/S mixed-layer mineral in one sample $(3049 \mathrm{~m})$. The R3 ordering is characterized for the deeper sample (3426 m; Figure 13). The percentage of illite in the mixed-layer illite/smectite was determined by the ${ }^{\circ} 2 \theta$ difference value of the peak positions $001 / 002$ and $002 / 003$ [50]. This proportion increases with depth from $75 \%$ to $90 \%$ over the analyzed depth interval (2700$4000 \mathrm{~m}$ ). A similar distribution was observed in the fine clay fraction, where illite, chlorite, and kaolinite are predominant and the amount of mixed-layer I/S is minor.

\section{Geochemical Data of Calcite}

Stable carbon and oxygen isotope compositions of calcite were measured mostly from bulk rock samples since more than one calcite phase occur in most of the samples (Figure 14; Table 3). The precompactional rhombohedral calcite (Cal1) could be separately sampled from sandstones of the Szolnok Formation. The values gave relatively narrow ranges $\left(\delta^{13} C_{\mathrm{V}-\mathrm{PDB}}\right.$ between 1.4 and $0.7 \%$ and $\delta^{18} \mathrm{O}_{\mathrm{V}-\mathrm{PDB}}$ between -6.0 and $-7.4 \%$, respectively). Bulk rock 


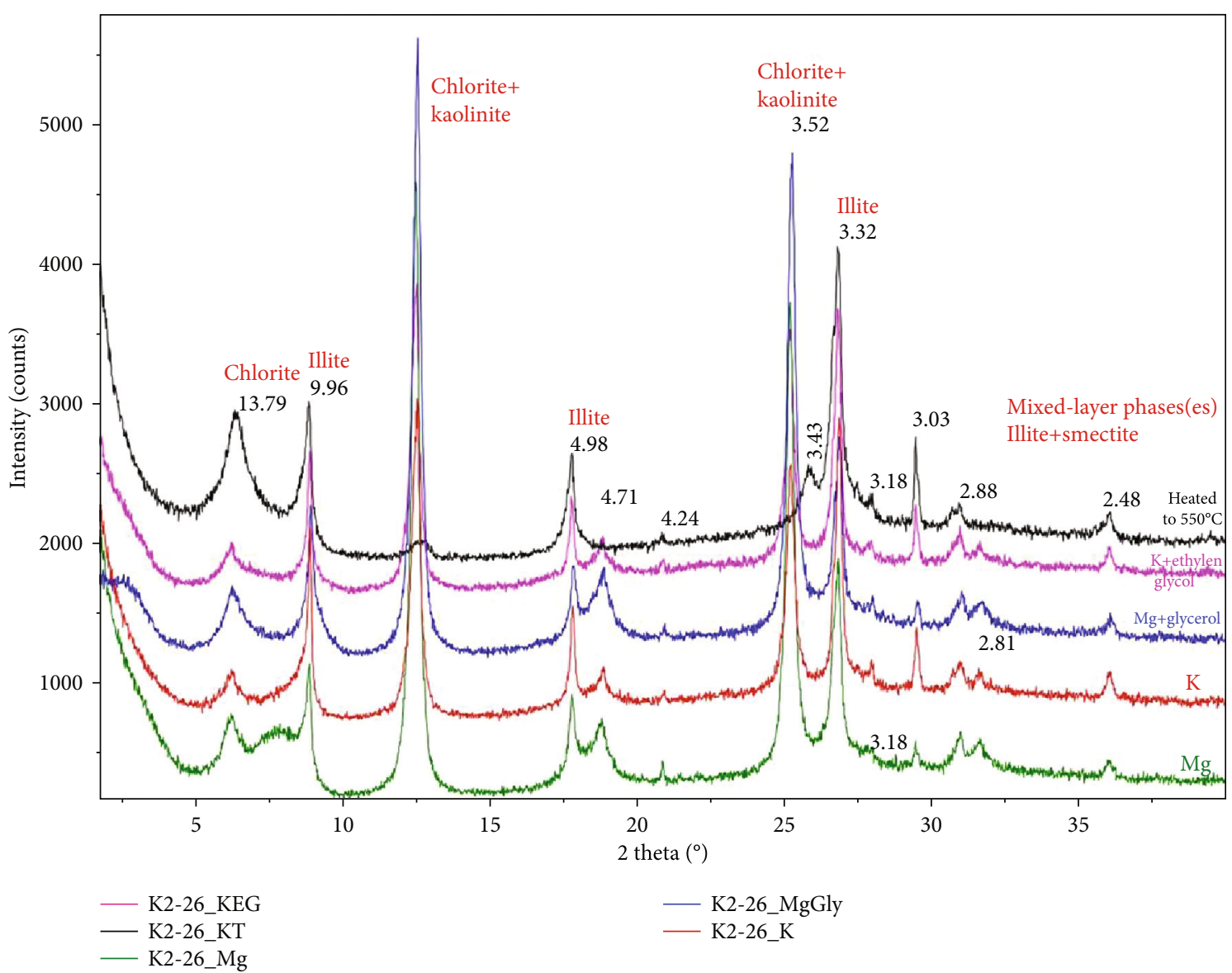

FIGURE 12: XRD patterns of oriented, $<2 \mu \mathrm{m}$ fraction samples of a characteristic sample from the Algyő Fm, $3051.43 \mathrm{~m}$.

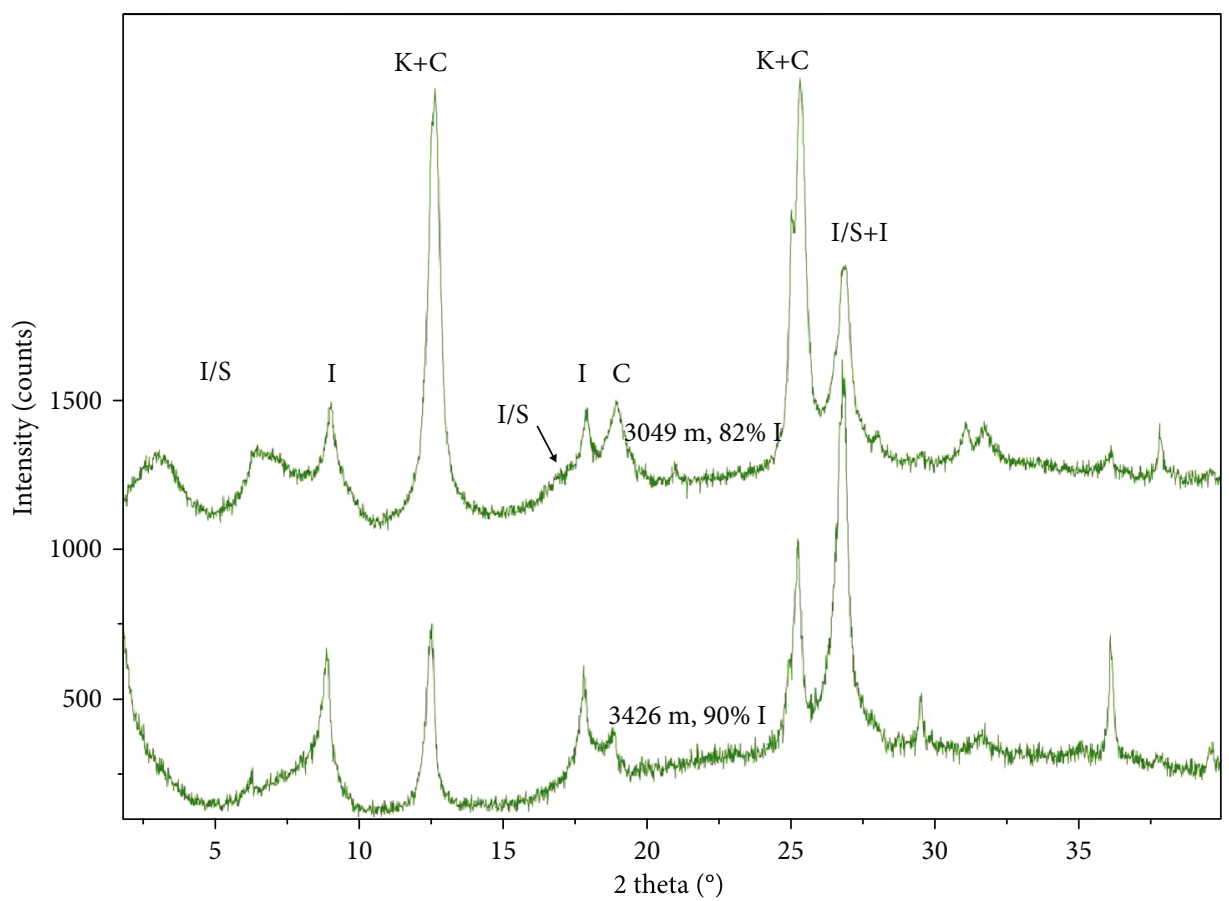

FIGURE 13: XRD patterns of oriented, EG-saturated $<0.2 \mu \mathrm{m}$ fraction samples. I/S: mixed-layer illite/smectite; I: illite; K: kaolinite; C: chlorite. Arrows show locations of I/S peaks. 


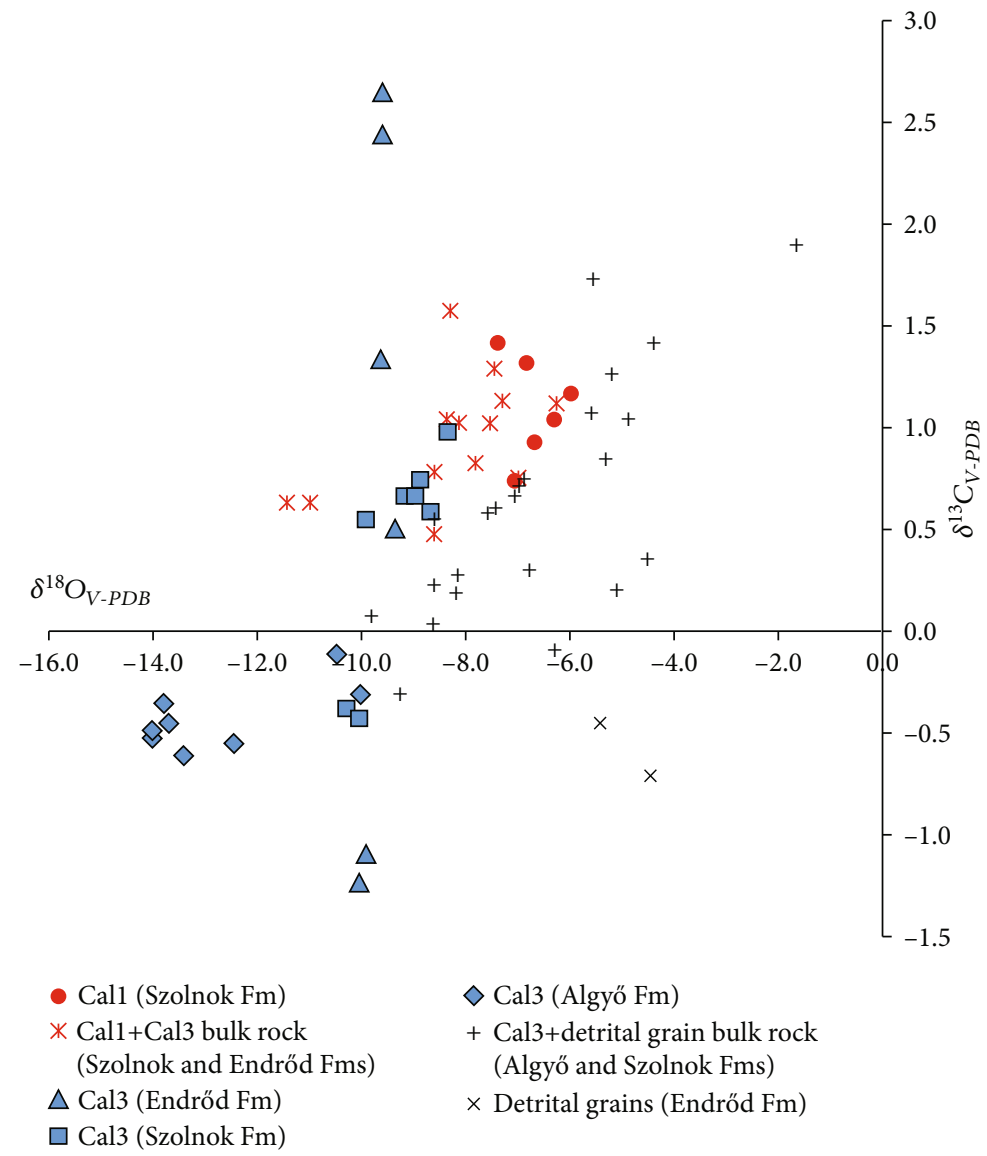

FIgURE 14: Stable oxygen and carbon isotopic composition of diagenetic and detrital calcite from the studied formations.

measurements of calcites (Cal1 and Cal3) from the same formation show an approximately similar carbon isotope ratio (from 1.1 to $0.6 \%$ ) but the oxygen isotope ratio yielded additionally more negative values as well (from -6.3 to $-11.4 \%$ ). These bulk rock values overlap with ratios measured from sandstones of the Endröd Formation, for $\delta^{13} C_{\mathrm{V}-\mathrm{PDB}}$ between 1.6 and $0.8 \%$ and for $\delta^{18} O_{\mathrm{V}-\mathrm{PDB}}$ between -7.4 and $-8.4 \%$, respectively.

Postcompactional calcite (Cal3) was measured from all the three formations. In most of the samples from the Szolnok and Algyő Formations, diagenetic calcite cooccurs with detrital calcite grains, and the measured ratios cover wide ranges between 1.0 and $-0.3 \%$ for $\delta^{13} C_{\mathrm{V}-\mathrm{PDB}}$ and between -1.6 and $-9.8 \%$ o for $\delta^{18} \mathrm{O}_{\mathrm{V}-\mathrm{PDB}}$. In the case of selective sampling of calcite (Cal3), where only a few detrital calcite grains are encountered, more negative oxygen values were obtained compared to the previous sample series. The oxygen isotope ratios are similar in sandstones of the two lower formations, ranging from -8.3 to $-10.3 \%$, whereas the calcite (Cal3) exhibits more negative oxygen values (from -10.0 to $-14.0 \%$ ) in the Algyö Formation. The carbon isotope ratio yielded a wide range in the Endröd Formation (from 2.6 to $-1.2 \%$ ) that overlaps with the values of the Szolnok Formation (from 1.0 to $-0.4 \%$ ). The calcite (Cal3) in the Algyö Formation is enriched in lighter carbon isotope showing negative values (from -0.3 to $-0.6 \%$ ). A distinct group of isotope values was measured from sandstones of the Endröd
Formation where calcite rock fragments and bioclasts are more abundant compared to other samples. The $\delta^{13} C_{\mathrm{V}-\mathrm{PDB}}$ values vary between -0.4 and $-0.7 \%$, and $\delta^{18} O_{\mathrm{V}-\mathrm{PDB}}$ values plot between -4.4 and $-5.4 \%$.

Elementary composition of calcite was analyzed on 20 samples (Figure 15). The majority of analyzed crystals are low- $\mathrm{Mg}$ calcite, in which the maximum amount of $\mathrm{MgCO}_{3}$ is approximately $3 \mathrm{~mol} \%$. Calcite (Call) in sandstones of the Endrőd Formation has a slightly higher $\mathrm{MgCO}_{3}$ content that can reach $6 \mathrm{~mol} \%$. The $\mathrm{MnCO}_{3}$ content is below $2 \mathrm{~mol} \%$ in every sample, whereas the $\mathrm{FeCO}_{3}$ content can reach $3 \mathrm{~mol} \%$ in the calcite ( $\mathrm{Cal} 3)$ measured from the Endröd Formation. Especially, calcite (Cal1) cement has low $\mathrm{FeCO}_{3}$ and $\mathrm{MnCO}_{3}$ contents. The $\mathrm{SrCO}_{3}$ content of the diagenetic calcites is mostly below $400 \mathrm{ppm}$. Calcite replacing feldspars have higher $\mathrm{SrCO}_{3}$ content than calcite cement.

\section{Discussion}

6.1. Paragenetic Sequence. Based on the petrographic features, textural relationships and geochemical data of the diagenetic components, a paragenetic sequence, can be established (Figure 16). The order of diagenetic components was examined relative to the mechanical compaction. The compaction was evaluated by contact types of the rigid framework grains and features of deformable grains. Thus, point, linear, and concavo-convex contacts were taken into 
TABLE 3: Stable oxygen and carbon isotope data of diagenetic and detrital calcite from the studied formations.

\begin{tabular}{|c|c|c|c|c|c|c|}
\hline Formation & depth & well & sample $N$ & $\delta^{18} \mathrm{O}$ & $\delta^{13} \mathrm{C}$ & Type of calcite \\
\hline Algyö & 2744.60 & B1 & b1-124 & -10.02 & -0.31 & $\mathrm{Cal3}$ \\
\hline Algyö & 3012.35 & K1 & kv10 & -13.39 & -0.61 & Cal3 \\
\hline Algyő & 3012.48 & K1 & $\mathrm{Kv}-1-3$ & -12.43 & -0.55 & Cal3 \\
\hline Algyő & 3039.06 & K1 & kv25 & -13.68 & -0.45 & Cal3 \\
\hline Algyő & 3044.76 & K1 & kv-2-17 & -13.99 & -0.52 & Cal3 \\
\hline Algyő & 3044.76 & K1 & kv14 & -13.78 & -0.35 & $\mathrm{Cal} 3$ \\
\hline Algyő & 3051.43 & K1 & kv15 & -10.45 & -0.11 & Cal3 \\
\hline Algyő & 3051.68 & K1 & $\mathrm{k} 2-27$ & -14.00 & -0.49 & $\mathrm{Cal} 3$ \\
\hline Algyő & 2743.75 & B1 & b1-123 & -8.18 & 0.19 & Cal3+ detr. Cal. g. \\
\hline Algyő & 2743.75 & B1 & b1-123 & -7.05 & 0.66 & Cal3+ detr. Cal. g. \\
\hline Algyő & 2744.60 & B1 & b1-124 & -8.61 & 0.04 & Cal3+ detr. Cal. g. \\
\hline Algyő & 3012.48 & K1 & $\mathrm{Kv}-1-3$ & -6.77 & 0.30 & Cal3+ detr. Cal. g. \\
\hline Algyő & 3019.94 & K1 & kv17 & -6.97 & 0.71 & Cal3+ detr. Cal. g. \\
\hline Algyő & 3020.94 & K1 & $\mathrm{kv} 24$ & -5.58 & 1.07 & Cal3+ detr. Cal. g. \\
\hline Algyő & 3020.25 & K1 & kv11 & -7.56 & 0.58 & Cal3+ detr. Cal. g. \\
\hline Algyő & 3020.92 & K1 & $\mathrm{kv}-1-13$ & -4.39 & 1.41 & Cal3+ detr. Cal. g. \\
\hline Algyő & 3020.92 & K1 & kv-1-13 & -8.59 & 0.23 & Cal3+ detr. Cal. g. \\
\hline Algyő & 3020.92 & K1 & kv-1-13 & -5.300 .85 & Cal3+detr. Cal. g. & Endrőd \\
\hline Algyő & 3023.59 & K1 & kv-1-24 & -4.871 .05 & Cal3+ detr. Cal. g. & Endrőd \\
\hline Algyő & 3023.49 & K1 & kv16 & -6.88 & 0.75 & Cal3+ detr. Cal. g. \\
\hline Algyő & 3036.84 & K1 & $\mathrm{kv}-2-5$ & -7.42 & 0.61 & Cal3+ detr. Cal. g. \\
\hline Algyő & 3036.84 & K1 & $\mathrm{kv}-2-5$ & -1.65 & 1.90 & Cal3+ detr. Cal. g. \\
\hline Algyő & 3036.84 & K1 & $\mathrm{kv}-2-5$ & -8.14 & 0.27 & Cal3+ detr. Cal. g. \\
\hline Algyő & 3036.84 & K1 & kv12 & -9.79 & 0.07 & Cal3+ detr. Cal. g. \\
\hline Algyő & 3039.24 & K1 & kv13 & -6.29 & -0.09 & Cal3+ detr. Cal. g. \\
\hline Algyő & 3056.43 & K1 & kv-2-26 & -9.25 & -0.30 & Cal3+ detr. Cal. g. \\
\hline Algyő & 3056.43 & K1 & kv-2-26 & -8.59 & 0.55 & Cal3+ detr. Cal. g. \\
\hline Szolnok & 4310.00 & M6 & m6cla & -10.29 & -0.37 & $\mathrm{Cal} 3$ \\
\hline Szolnok & 4310.00 & M6 & $\mathrm{m} 6 \mathrm{clb}$ & -10.04 & -0.43 & Cal3 \\
\hline Szolnok & 4099.45 & M7 & 39 & -8.35 & 0.98 & Cal3 \\
\hline Szolnok & 4099.45 & M7 & 39 & -9.17 & 0.67 & Cal3 \\
\hline Szolnok & 4099.45 & M7 & $\mathrm{m} 739 \mathrm{a}$ & -8.97 & 0.67 & $\mathrm{Cal} 3$ \\
\hline Szolnok & 4103.49 & M7 & $\mathrm{m} 743 \mathrm{~b}$ & -8.87 & 0.75 & Cal3 \\
\hline Szolnok & 3602.12 & Mcs1 & 82 & -9.92 & 0.55 & Cal3 \\
\hline Szolnok & 3421.22 & M7 & 69 & -8.68 & 0.59 & Cal3 \\
\hline Szolnok & 3412.96 & M7 & 16 & -6.68 & 0.93 & Call \\
\hline Szolnok & 3602.45 & Mcs1 & 78 & -6.31 & 1.04 & Call \\
\hline Szolnok & 3602.45 & Mcs1 & 78 & -5.99 & 1.17 & Call \\
\hline Szolnok & 4088.95 & M7 & 48 & -7.38 & 1.42 & Cal1 \\
\hline Szolnok & 4088.95 & M7 & 48 & -6.83 & 1.32 & Cal1 \\
\hline Szolnok & 4087.79 & M7 & $\mathrm{m} 7-46$ & -7.07 & 0.74 & Cal1 \\
\hline Szolnok & 3602.12 & Mcs1 & 82 & -11.42 & 0.63 & Cal1 + Cal3 \\
\hline Szolnok & 3602.12 & Mcs1 & 82 & -6.25 & 1.12 & Cal1 + Cal3 \\
\hline Szolnok & 3602.12 & Mcs1 & 82 & -10.98 & 0.63 & Cal1 + Cal3 \\
\hline Szolnok & 3602.12 & Mcs1 & $\operatorname{mcs} 82 \mathrm{a}$ & -6.98 & 0.75 & $\mathrm{Cal} 1+\mathrm{Cal} 3$ \\
\hline Szolnok & 4086.21 & M7 & $\mathrm{m} 744 \mathrm{a}$ & -8.59 & 0.78 & Cal1 + Cal3 \\
\hline Szolnok & 3412.96 & M7 & 16 & -5.55 & 1.73 & Cal3+ detr. Cal. g. \\
\hline Szolnok & 3420.52 & M7 & $\mathrm{m} 768 \mathrm{a}$ & -5.20 & 1.26 & Cal3+ detr. Cal. g. \\
\hline
\end{tabular}


TABLe 3: Continued.

\begin{tabular}{|c|c|c|c|c|c|c|}
\hline Formation & depth & well & sample $N$ & $\delta^{18} \mathrm{O}$ & $\delta^{13} \mathrm{C}$ & Type of calcite \\
\hline Szolnok & 3426.60 & M7 & $\mathrm{m} 7 \mathrm{c} 2-75$ & -4.49 & 0.35 & Cal3+ detr. Cal. g. \\
\hline Szolnok & 3426.60 & M7 & $\mathrm{m} 7 \mathrm{c} 2-75$ & -5.10 & 0.20 & Cal3+ detr. Cal. g. \\
\hline Endrőd & 4060.40 & Mcs1 & 88 & -7.45 & 1.29 & Cal1 + Cal3 \\
\hline Endrőd & 4060.40 & Mcs1 & 88 & -8.36 & 1.04 & Cal1 + Cal3 \\
\hline Endrőd & 4060.40 & Mcs1 & 88 & -8.13 & 1.02 & Cal1 + Cal3 \\
\hline Endrőd & 4061.85 & Mcs1 & $\operatorname{mcs} 98 \mathrm{c} 1$ & -7.81 & 0.83 & Cal1 + Cal3 \\
\hline Endrőd & 4061.85 & Mcs1 & $\operatorname{mcs} 98 \mathrm{c} 1$ & -8.28 & 1.57 & Cal1 + Cal3 \\
\hline Endrőd & 4759.40 & M7 & $\mathrm{m} 761 \mathrm{a}$ & -8.59 & 0.48 & Cal1 + Cal3 \\
\hline Endrőd & 4760.80 & M7 & 62 & -7.53 & 1.02 & Cal1 + Cal3 \\
\hline Endrőd & 4760.80 & M7 & 62 & -7.29 & 1.13 & Cal1 + Cal3 \\
\hline Endrőd & 5470.26 & M7 & $\mathrm{m} 7 \mathrm{c} 6-106$ & -9.60 & 2.65 & Cal3 \\
\hline Endrőd & 5472.65 & M7 & $\mathrm{m} 727 \mathrm{a}$ & -9.63 & 1.34 & Cal3 \\
\hline Endrőd & 5472.65 & M7 & $\mathrm{m} 727 \mathrm{a}$ & -9.58 & 2.44 & Cal3 \\
\hline Endrőd & 5050.00 & M6 & $\mathrm{m} 6 \mathrm{c} 3 \mathrm{~b}$ & -9.89 & -1.09 & Cal3 \\
\hline Endrőd & 5050.00 & M6 & $\operatorname{mc} 63 \mathrm{c}$ & -9.35 & 0.51 & Cal3 \\
\hline Endrőd & 4061.85 & Mcs 1 & $\operatorname{mcs} 98 \mathrm{c} 1$ & -10.03 & -1.23 & Cal3 \\
\hline Endrőd & 4061.85 & Mcs1 & $\operatorname{mcs} 98 \mathrm{c} 1$ & -4.45 & -0.71 & detrital calcite grains \\
\hline Endrőd & 4061.85 & Mcs1 & $\operatorname{mcs} 98 \mathrm{c} 1$ & -5.42 & -0.45 & detrital calcite grains \\
\hline
\end{tabular}

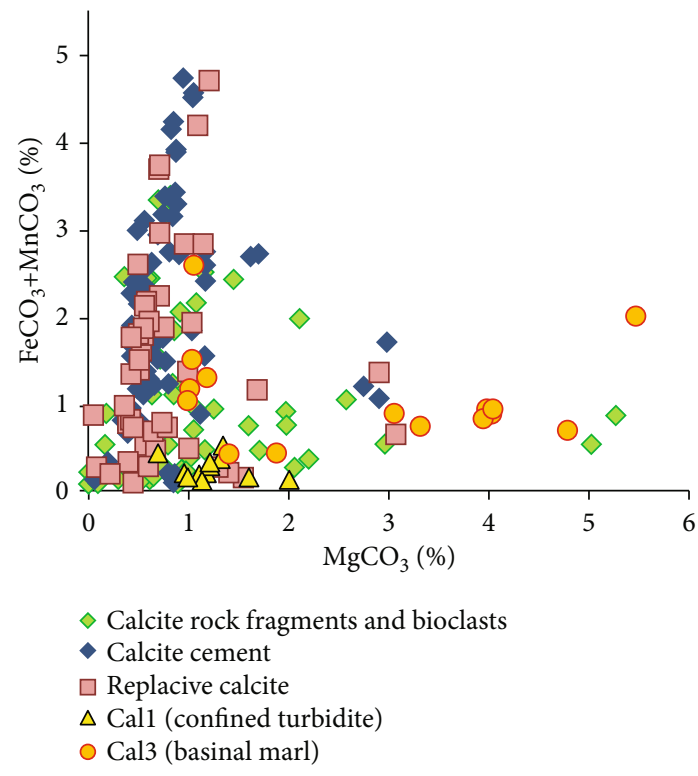

FIGURE 15: Elementary composition of calcite.

consideration. Although the intergranular volume (IGV) is normally regarded as a key parameter in establishing estimates for compaction [60], using the volume of calcite to estimate the IGV was not possible since calcite crystals commonly replaced precursor detrital grains.

Clay coats on grain surfaces suggest that at the time of their formation, the pore space was comparable to the primary pore space of the sediment [61]. Accordingly, this process predated compaction, although it was insignificant in the studied succession. The precipitation of framboidal pyrite has been described as a microbially mediated process (bacte- rial sulphate reduction; BSR) which takes place at temperatures lower than $60-80^{\circ} \mathrm{C}$ [62-64]. Since continuous burial without uplift was documented from the Makó Trough [65], framboidal pyrite formed during early diagenesis. Relationships of calcite cements (Call and Cal2) to sedimentary grains (overlapped by bended mica and fine grains and engulfing point contacts, respectively) suggest that these crystals were precipitated in the primary intergranular pore space before mechanical compaction.

Albite, ankerite, and quartz cement engulf linear grain contacts, implying postcompactional origin. In the Szolnok Formation, a thin alteration rim consisting of Fe dolomite cooccurs along with ankerite, pointing to initiation of a process as replacement. Intergrowth between microcrystalline quartz, illite, and chlorite indicates their simultaneous formation. Ferroan calcite crystals (Cal3) engulf linear grain contacts and occlude the reduced primary intergranular pore space. Calcite (Cal3) replaces ankerite and engulfs diagenetic albite. Additionally, the postdating relation to overgrowth quartz cement in the Algyö Formation indicates late timing of calcite (Cal3) in the paragenetic sequence. Many studies have shown that syntaxial overgrowth quartz cementation is primarily temperature-dependent and plays a crucial role during burial of sandstones [66]. In most of the sedimentary basins, the minimum formation temperature for quartz overgrowth is $70^{\circ} \mathrm{C}[67,68]$. The presence of the solid bituminous organic matter indicates hydrocarbon migration since it occurs along pressure dissolution surfaces and postdates the latest cementation stage in sandstones of the Algyö Formation.

Open secondary porosity, accompanied by aggregates of finely crystalline pyrite and organic matter, postdates quartz and calcite (Cal3) cement precipitation in the Algyö Formation. Skeletal feldspar and calcitic grains as well as corroded 


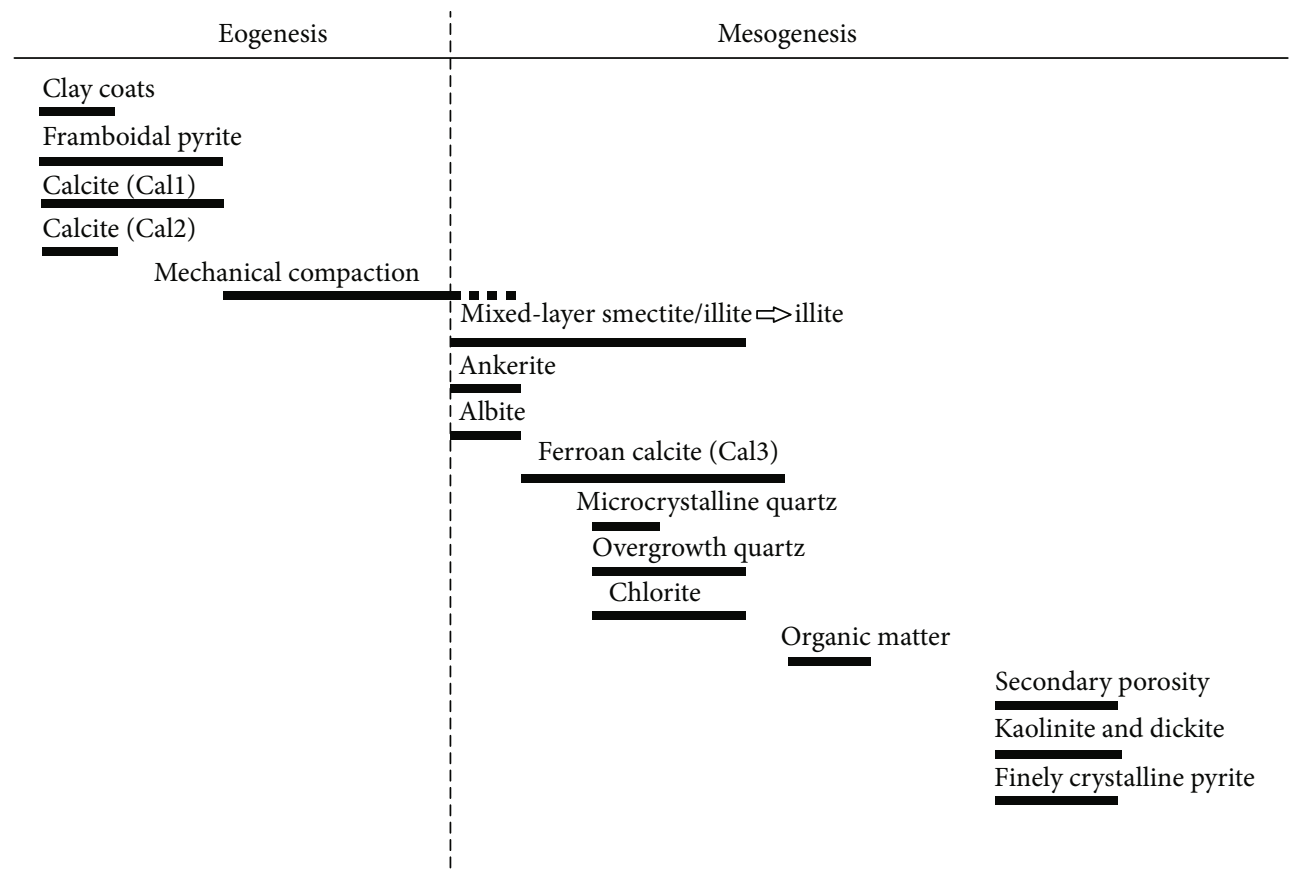

Figure 16: Paragenetic sequence of sandstones in the three studied formations.

calcite (Cal3) cement, typified by intragranular and intracrystalline porosity, indicate a dissolution process late in the paragenetic sequence. The presence of pyrite along the open pores suggests the alteration of the precursor migrated organic matter, likely by thermochemical sulphate reduction (TSR; compare [62]), and also indicates sulphate-rich extraformational fluid flow. Since kaolinite/dickite postdates quartz cement in the studied succession, it is interpreted as being formed late in the paragenetic sequence. Kaolinite is intimately associated with corroded feldspars and open pores; additionally, it engulfs the linear contact of the grains.

Cubic pyrite in the Endröd Formation likely formed in the zone of thermochemical sulphate reduction $[26,43]$.

6.2. Interpretation of Stable Isotopes of Calcite Phases. Unaltered aragonite shells of the Pannonian age were collected from surface locations and were analyzed for carbon and oxygen isotope ratios in order to provide a detailed palaeoenvironmental interpretation [69]. The analyzed whole-shell carbon isotope ratios range between 2.1 and $0.3 \%$, and the average value is $1.4 \%$ [69]. These values show good correlation with the isotope ratios of precompactional calcite (Cal1) cement measured from the studied sandstones. Moreover, Fe and $\mathrm{Mn}$ concentration of this calcite (Cal1) phase are very low. These data together imply an early precipitation of calcite (Cal1) from connate pore water (cf. [70] [59];). The carbon isotope ratios of late calcite ( $\mathrm{Cal} 3)$ cover a wide range overall in the case of the three studied formations, and the majority of the measured isotope ratios show lower values compared to calcite (Cal1) cement and the Pannonian aragonite shells. This negative shift in carbon isotope values indicates an organic carbon supply. Since calcite (Cal3) in the Algyő Formation appears late in the diagenetic sequence, postdating microcrystalline and overgrowth quartz cements, and predating migration of organic matter (which was preserved along dissolution surfaces), the additional light isotope was likely sourced from fluids flow ahead of the migrating organic matter (cf. [2]).

The isotopic data in combination with palaeofaunal evidence indicates that Pannonian lake water was brackish [69]. The tectonosedimentary evolution of the asymmetric extensional system was driven by the activity of a low-angle listric normal fault, which was located on the southwestern side of the Makó Trough [35, 37]. The studied cores were cut in the basin centre and on the northeastern/eastern hanging wall flank. During diagenesis, the meteoric water recharge-through subaerially exposed, topographically elevated blocks - which would have supplied additional light oxygen isotope, can be ruled out based on the facies reconstruction and the continuous burial of the deposits in the Makó Trough $[22,24]$. Gradual transgression resulted in flooding of almost the entire Pannonian Basin, including the adjacent basement highs of the Mako Trough, at the stage of deposition of the Endröd Formation [32]. Accordingly, the negative shift in the oxygen isotope ratios of diagenetic calcite phases-which is compared to that of Pannonian aragonite shells, calculating with $0.6 \%$ fractionation between aragonite and calcite $[71,72]$ - is interpreted as being the reflection of increasing precipitation temperature during burial. In the Szolnok Formation, bulk rock calcite (Cal1 and Cal3), in samples from the basin margin succession, yielded more negative values than the separately measured calcite (Cal3) in samples from the basin centre. This feature likely indicates that at marginal settings, the calcite ( $\mathrm{Cal} 3$ ) precipitation continued as well as at slightly higher temperature.

Detrital calcite grains, stained pink, in the sandstone interbeds of calcareous marls have a distinct isotope composition, which is characterized by relatively negative carbon 
values. Isotope composition and low Fe concentration of the detrital calcite grains suggest meteoric diagenetic alteration of carbonate rock bodies before reworking of the grains. Negative carbon isotope values of diagenetic calcite in this unit indicate nucleation of crystals on such type of precursor detrital grains and mineral replacement diagenetic process (cf. [73]).

6.3. Sources of Diagenetic Reactions. In the studied succession, the diagenetic processes are interpreted according to the diagenetic realms, which were adapted from the model by Morad [67]. The eogenetic and early stage mesogenetic mineral associations (calcite, chlorite, and illite) are in accordance with the observations of Mátyás [44] and Mátyás and Matter [27]. The deeply buried sandstones are of low hydraulic connectivity, and the eogenetic and early stage mesogenetic reactions were sourced from internal reactions of unstable components and connate brackish pore water of the deposits. In the uppermost part of the Szolnok Formation and in the Algyő Formation, the sandstones contain secondary open porosity that was generated by dissolution. This indicates extraformational fluid flow during the late stage of mesogenesis.

6.3.1. Eogenetic Reactions. Primary pore-filling and graincoating clay minerals can have various origins, such as inherited coats, infiltrated coats, and/or bioturbation [61, 74-76]. According to Wooldridge [77], the clay particle attachment is mediated by a biofilm; thus, biological mediation plays a crucial role in the formation of grain coats. Bioturbation occurs in clay-rich layers of the Endröd Formation as well as in the turbidite formations; thus, a biomediated condition was assured for the formation of clay coats. Euhedral and subhedral forms of single calcite crystals (Cal1) and the overlapping fine-grained particles imply that this cement phase was precipitated in highly porous and unconsolidated sediments via displacive growth (cf. [78]). Very similar features of calcite cement were reported from deep-sea deposits where the cement crystals nucleated on coccoliths [79-82]. Nannoflora is ubiquitous, especially in the calcareous marl unit of the Endröd Formation, but it occurs in the lower part of the Szolnok Formation as well [83].

Framboidal pyrite precipitation via BSR from connate pore water was controlled by the sulphate content that indicates brackish water in the sedimentary environment. Eogenetic origin of framboidal pyrite is in accordance with the interpretation of the published study on the Endröd Formation by Varga et al. [42]. Redox reactions took place between sulphate and organic matter incorporated into marls and resulted in calcite and pyrite crystals as by-products [55]. The reaction generated acidity due to released organic acids and $\mathrm{CO}_{2}$ that likely triggered the dissolution of some of the cooccurring very finely crystalline coccoliths. The dissolved compounds were precipitated in sandstone interlayers via nucleation on coccolith skeletons as displacive calcite cement (Cal1) and on framework grains as calcite cement film (Cal2). The latter locally prevented the compaction of deposits. An additional reaction product was $\mathrm{HS}^{-}$that removed Fe from the water [55]. This latter reaction explains the low Fe con- centration of the precompactional calcites (pink stained Cal1 and brighter luminescent Cal2). The amount of precompactional calcites was likely limited by the sulphate content of connate brackish pore water.

Analogues of the above-described shallow burial diagenesis can be found in diagenetic couplets of marls and calcitecemented sandstones, which were studied in detail in marine settings. Matter [84] and Czerniakowski et al. [85] described the stages of diagenesis of deep-water marls and chalks. In those rocks, discoasters and coccoliths as well as sedimentary particles form nucleii on which finely crystalline calcite cement precipitated during shallow burial. They concluded that $\mathrm{CaCO}_{3}$ cement can be sourced from the dissolution of the more readily soluble fine-grained carbonate particles.

6.3.2. Early Stage Mesogenetic Reactions. The proportion of illite in mixed-layer illite/smectite gradually increases with depth and the transition from R1 to R3 ordering occurs at a depth of around $3400 \mathrm{~m}$. In the deepest analyzed sample $(4087 \mathrm{~m})$, the smectite-to-illite transformation reaction is complete, and only discrete illite can be found. This is in accordance with the results of Hillier et al. [86] published from the Makó Trough. Ankerite in sandstones mainly occurs in the zone of mesogenesis and in many cases, it is connected to the transformation of clay minerals, because this reaction involves loss of iron and magnesium [87-90]. In the Makó Trough, ankerite is postcompactional, as it engulfs linear grain contacts, and its amount slightly increases with depth. This suggests that its formation was coeval with clay mineral transformations. Later on, calcite (Cal3) replaced and postdated ankerite. Ankerite is one of those minerals that tend to nucleate exclusively on the surfaces of specific preexisting crystals [59]. In the studied sandstones, diagenetic ankerite initiated with replacement of the outer area of detrital dolomite grains and continued as cement precipitation. All these features suggest that ankerite began to form at around $50^{\circ} \mathrm{C}$ at the same time as clay mineral transformations. Accordingly, the ankerite distribution was controlled by the chemical drive and the availability of dissolved $\mathrm{Fe}$ and $\mathrm{Mg}$ in pore fluids.

Albite is a widespread diagenetic mineral in the examined samples, and its amount increases with depth. In the shallower samples, the albitization of feldspar is partial, whereas in deeper samples (deeper than $4000 \mathrm{~m}$ ), the detrital feldspars are completely albitized. In the latter case, albite overgrowth cement is also present. The albite is nonluminescent, suggesting a diagenetic origin (cf. [91]). The burial trend indicates that albitization was a temperature-controlled process in the Makó Trough. Albitization of detrital K-feldspar is a common diagenetic alteration process in reservoir sandstones and occurs within a temperature range of 65 to $125^{\circ} \mathrm{C}$ [92]. The illitization of smectite was interpreted as the source for albitization and quartz cementation in the studied sandstones (cf. [91] [68],).

Quartz cement is generally observed as the most abundant diagenetic component in clean quartz arenites with low clay content [93]. In the studied samples, quartz cement is most widespread in the Algyö Formation, which also has a high detrital quartz content. Otherwise, quartz cement is 


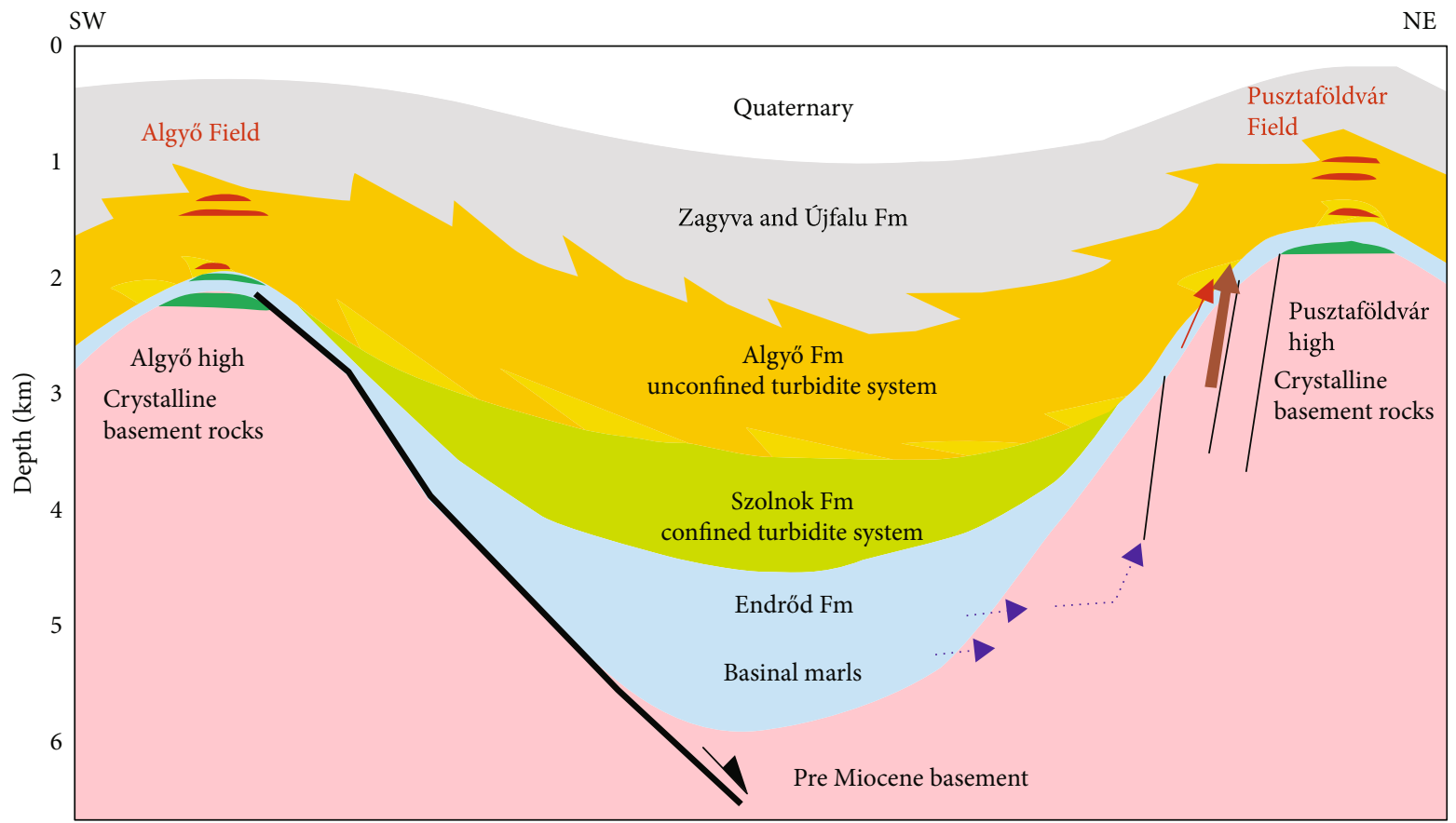

Fluid flow model

$\longrightarrow$ Stage 1. hydrocarbon migration pathway on hanging wall flank (from open-water marls to directly overlying turbidite sandtones)

Stage 1. overpressured fliud flow (from open-water marls into fractures of crystalline basement rocks)

Stage 3. palaeobrackish fluid flow (recharged during the flooding of Lake Pannon into fracture systems of crystalline basement rocks, trapped during subsidence and discharged into turbidite sandstones by pressure of fluids originated from open-water marls)

Y

Master fault of sub basin

Fracture system in crystalline basement

$\approx$ Hydrocarbon fields

Figure 17: Reconstruction of fluid flows for the studied northeastern segment of the Makó Trough, which is located at the passive margin setting near the Pusztaföldvár High. This model is adapted and modified after Juhász et al. [109], which was previously proposed for a neighboring subbasin (Békés Basin). The schematic section is based on seismic profile (data compiled from Bada et al. [23] and Molnár et al. [110]). Sandy turbidite lobes are marked in yellow at the lower part of the Algyö Fm. Blue arrows indicate hydrologic connection between the basinal deposits and the fractured basement rocks. The thick brown arrow indicates the origin of sulphate-rich extraformational fluid, which was responsible for creating the open porosity in sandstones in the deep burial realm. Red arrows indicate the kerogen migration-according to the model by Szalay and Koncz [47], Magyar et al. [48], and Bada et al. [22]—from which the organic matter was preserved as streaks of residual bitumen in the upper turbidites (Algyő Fm).

extremely scarce in the lower two formations, which are rich in feldspar grains and rock fragments. Intergrowth of microcrystalline quartz with illite and chlorite indicates coeval formation. According to Bjorkum [94], the presence of K- and Al-bearing minerals (illite, micaceous clay) on the surfaces of quartz grains can enhance pressure dissolution and quartz cementation. Mica flakes are widespread on the surfaces of quartz grains in the studied sandstones, suggesting a possible source for quartz cementation. In the lower two formations, only microcrystalline quartz cement is encountered. In these sandstones, the primary pore space was reduced by compaction, ankerite, and calcite ( $\mathrm{Cal} 3$ ) cementation, suggesting cement crystal precipitation below the temperature range of quartz cementation. In most of the sedimentary basins, the minimum formation temperature for quartz is $70^{\circ} \mathrm{C}[67,68]$.

Authigenic chlorite in sandstones has been reported over a wide range of temperatures from 70 to $200^{\circ} \mathrm{C}$ and is characterized for the mesogenetic realm [95-99]. Grain-coating chlorite commonly plays a significant role in preventing quartz cementation and enhancing or preserving reservoir quality $[15,16,96$, 98], but due to the very small quantity in the studied sandstones, this effect is negligible. Authigenic chlorite in the studied sandstones was likely sourced from eogenetic precursor minerals, such as berthierine, kaolinite, and smectite (cf. [98]), or from 
the dissolution of detrital grains and volcanic rock fragments (cf. [100]). In the Makó Trough, the majority of chlorite are of a detrital origin, which was transported from eroded metamorphic basement rocks [34].

Since the replacive calcite $(\mathrm{Cal} 3)$ is localized near altered K-feldspars, dolomite, ankerite, and other detrital carbonate grains, the chemical drive of nucleation and the internal source of replacive calcite in this case are obvious (cf. [66, $101,102])$. Small ferroan calcite (Cal3) crystals occluded the compactionally reduced primary intergranular pore space that suggests the cementation of sandstones which was fed by pressure dissolution of fine-grained detrital carbonates. The estimated temperature range of ferroan calcite (Cal3), in the case of the lower two formations, is lower in the basin centre and somewhat higher in flank areas, as is reflected by the oxygen isotope ratios. The Fe content of the crystals likely originates from the coeval clay mineral transformations (cf. [59]). These features imply a common compactioncementation lithification of sandstone-mudstone couplets as described by Matter [84]. Silt-sized carbonate particles are abundant in the Endröd Formation, many of which are likely remnants of nannoflora and planktonic foraminifers [83]. Accordingly, the precipitation of ankerite was terminated by overwhelming abundance of $\mathrm{Ca}^{2+}$ in pore fluids that was a result of carbonate dissolution in marl interbeds and compactionally driven fluid flow to sandstones. The characteristic feature of calcite, that no special nucleation substrate is required, also contributed to switching on calcite cementation. The carbon and oxygen isotope ratios of ferroan calcite (Cal3) exhibit a linear correlation, especially in the sandstones of the Szolnok and Algyö Formations. This feature also refers to rock-buffered dissolution and reprecipitation of $\mathrm{CaCO}_{3}$ where at higher temperature, additional light carbon isotope was sourced from organic matter maturation taking place in the underlying marls. In the Szolnok Formation, the laterally increasing trend (from centre to margin) in the amount of ferroan calcite (Cal3) crystals as well as in the estimated precipitation temperature (based on the trend in the oxygen isotope ratios) indicates compaction-driven fluid flow, directed laterally and upwards. Pervasive calcite cementation was estimated to occur below $70^{\circ} \mathrm{C}$ in sandstones of the lower two formations, which prevented the precipitation of other minerals, i.e., quartz cement. Higher estimated temperature of calcite $(\mathrm{Cal} 3)$ cement $\left(\right.$ above $70^{\circ} \mathrm{C}$ ) is consistent with the petrographic feature that calcite (Cal3) and quartz cement crystals have compromise boundaries.

In the sandstones of the Algyő Formation, remnants of the migrated organic matter were detected along concavoconvex grain contacts. This feature indicates that hydrocarbon migration occurred when the formation had minor porosity, and pore fluids localized along pressure dissolution surfaces. At the marginal setting (where this turbidite formation was studied), the hydrocarbons originated from the directly underlying open-water marls as source rocks (Endröd Formation [39, 103];) and migrated after maturation. The measured formation temperature in these wells is $100^{\circ} \mathrm{C}$.

6.3.3. Late Stage Mesogenetic Reactions. Secondary porosity in authigenic calcite, which is one of the latest diagenetic minerals, indicates that a dissolution process took place in the deep burial realm. The presence of finely crystalline pyrite implies that the secondary vuggy porosity postdated hydrocarbon migration and was generated by thermochemical sulphate reduction (TSR). The observed open porosity, which postdates quartz cementation, suggests extraformational fluid flow. Water containing sulphate was trapped and stored in the fracture system of crystalline (metamorphic and dolomite) basement rocks, and later, on these were flooded by the brackish water of Lake Pannon. During late stage of burial, in the centre of the subbasin, the developing overpressure in deeply buried open-marine source rock marls [104] likely triggered the fluids to flow laterally into the fracture system of uplifted basement highs (Figure 17). Results of computer modeling suggest that because of their rather special structural position, the basement highs govern fluid flow like a chimney [105].

Kaolinite was formed via alteration of feldspar in the studied sandstones. Formation of kaolinite has been reported from many reservoir sandstones, and it is connected to either meteoric fluid recharge or organic matter maturation [94, $106,107]$. In the mesogenetic realm, kaolinite is commonly related to acidic fluids generated in organic-rich deposits during hydrocarbon maturation $[2,7,108]$. In the studied sandstones, kaolinite postdates quartz cementation that indicates a deep burial origin. Kaolinite accompanied the latestage open porosity development where TSR reactions created an acidic environment.

6.4. Hydrologic Connection between Basinal Deposits and Basement Blocks-Revised Model. Secondary porosity development, in a fluid-dominated system at a late stage of diagenesis, can be integrated into the model proposed by Juhász et al. [109]. This model describes a long-standing hydrologic connection between the uplifted and fractured crystalline basement highs, and the Pannonian deposits in the neighboring subbasin (Békés Basin). The key elements of the hydrogeologic model are [1] the exhumation and subaerial exposure of crystalline rocks, [2] the meteoric water percolation and recharge into the basinal deposits, and [3] the following basin-wide thermal subsidence and hydraulic inversion.

In the Pannonian Basin, the back-arc extension resulted in the opening of a significant number of subbasins separated by uplifted basement highs $[35,36]$. The main controlling structure was a low-angle listric normal fault that accommodated the subsidence of subbasin and the uplift of the adjacent footwall [34]. The uplift was associated with subaerial exposure and erosion at the structural culmination of the footwall. The basement highs were islands or peninsulas in Lake Pannon [32]. During the rift climax, the highs became submerged. Open-water marls of the Endröd Formation either overlie basal conglomerates or rest directly on crystalline basement [40].

Mátyás [44], Mátyás and Matter [27], Mátyás et al. [69] and Juhász et al. [109, 111] reported significant amounts of kaolinite from the Szolnok Formation as well as from basal conglomerate formation deposited on the active margin of other subbasins. These studies proposed that diagenesis in 
shallow-buried sandstones close to basement highs was most likely governed by descending meteoric water channeled by fractures of elevated basement rocks. The sedimentary model of the Makó Trough shows that at the time of shallow burial of the Szolnok Formation, the basement highs were already covered with open-water marly-silty sediments [24]. Integration of the previous diagenetic results with the sedimentary and geodynamic models implies that eogenetic diagenetic alteration via meteoric fluids did not occur in the studied deep subbasin.

Petroleum migration, from underlying Miocene source rocks through the fracture system of basement rocks, was described by Schubert et al. [105]. According to observations on fluid inclusions [27, 105], a newly established hydrologic connection occurred in the deep burial realm between the basinal deposits and the basement blocks. Molnár et al. [110] also demonstrated that the dense fracture network of the basement behaves as a migration pathway toward the overlying sandstone deposits. A very thick sedimentary succession in the rapidly subsiding subbasins of the Makó Trough generated overpressure in the Endröd Formation that likely triggered the fluid flow upward through the basement fractures. In the present study, the sandstone diagenesis from the Makó Trough revealed that late-stage kaolinite/dickite and open porosity in those sediments located on the passive margin of the subbasins are the indicators of an external fluid-dominated system. Brackish water containing sulphate was trapped and stored in the fracture system of crystalline (metamorphic and dolomite) basement rocks when the water of Lake Pannon flooded.

\section{Conclusions}

In order to evaluate the differences in porosities and permeability in Upper Miocene lacustrine deep-water sandstones of the Endrőd, Szolnok, and Algyő Formations, a detailed diagenetic study from core samples from a deeply buried, asymmetric extensional subbasin of the Pannonian Basin was carried out. In the deposits located in the passive marginal setting, the majority of diagenetic alterations were sourced internally. These diagenetic components reflect a general burial trend that is commonly recorded in siliciclastic basins: In sequential order, these are framboidal pyrite, precompactional calcite, ankerite, albite, quartz, postcompactional ferroan calcite, bituminous organic matter, and clay minerals, such as illite and chlorite. Consequently, the studied sandstones were tightly cemented. Remnants of the migrated organic matter were observed only along pressure dissolutional surfaces.

Open porosity in the sandstones of the Algyö Formation along with the upper zone of the Szolnok Formation developed together with finely crystalline pyrite and kaolinite/dickite during the late stage of diagenesis, indicating an open diagenetic system and external fluid source. The recharging brackish fluid implies local hydrologic connection between the basinal deposits and the basement high. The findings of this study add a unique element to the previously proposed hydrologic model and describe the complex interactions between basinal deposits and basement blocks.

\section{Data Availability}

The data used to support the findings of the study can be available within the article.

\section{Conflicts of Interest}

The authors declare that they have no conflicts of interest.

\section{Acknowledgments}

This paper is based on the $\mathrm{PhD}$ research of the first author. Dr. Gábor Bada and TXM Ltd are acknowledged for providing samples from the Makó Trough and for their help during the study. We are grateful to Dr. Tomáš Mikuš for the electron microanalysis and to Zoltán Kovács, Kristóf Fehér, István Oláh, and Dr. Christian Baal for the SEM analysis. Dr. Orsolya Győri, Dr Andrea Mindszenty, Dr. László Fodor, Dr Attila Balázs, Lilla Tőkés, and Dr. János Mátyás are thanked for the discussions on the topic. The comments and suggestions of Dr. Sándor Józsa, Dr. Gianni Mallarino, Dr. György Czuppon, and Dr. Andrea Raucsikné-Varga are gratefully acknowledged. Microscopic and various analytical measurements were carried out at MTA-ELTE Geological, Geophysical, and Space Sciences Research Group (Budapest), Eötvös Loránd University, Department of Geology, (Budapest), University of Vienna, Department of Geodynamics and Sedimentology, and Slovak Academy of Sciences (Banska Bystrica). These analyses were financially supported by the Papp Simon Foundation and NTP-NFTÖ-16 grant of the Hungarian Ministry of Human Capacities. The authors appreciate the constructive comments and suggestions of Dr. Benjamin Brigaud and the anonymous reviewer, handling editor, and managing editor. The authors are grateful to Henry Lieberman for the English grammar correction.

\section{References}

[1] J. Lai, G. Wang, Z. Fan et al., "Insight into the pore structure of tight sandstones using NMR and HPMI measurements," Energy and Fuels, vol. 30, no. 12, pp. 10200-10214, 2016.

[2] T. R. Taylor, M. R. Giles, L. A. Hathon et al., "Sandstone diagenesis and reservoir quality prediction: Models, myths, and reality," American Association of Petroleum Geologists Bulletin, vol. 94, no. 8, pp. 1093-1132, 2010.

[3] J. M. Ajdukiewicz and R. H. Lander, "Sandstone reservoir quality prediction: The state of the art," American Association of Petroleum Geologists Bulletin, vol. 94, no. 8, pp. 1083-1091, 2010.

[4] S. P. Dutton, "Calcite cement in Permian deep-water sandstones, Delaware Basin, west Texas: origin, distribution, and effect on reservoir properties," American Association of Petroleum Geologists Bulletin, vol. 92, no. 6, pp. 765-787, 2008.

[5] S. Schmid, R. H. Worden, and Q. J. Fisher, "Diagenesis and reservoir quality of the Sherwood Sandstone (Triassic), Corrib Field, Slyne Basin, west of Ireland," Marine and Petroleum Geology, vol. 21, no. 3, pp. 299-315, 2004.

[6] R. H. Worden and S. D. Burley, "Sandstone diagenesis: the evolution of sand to stone," in Sandstone Diagenesis: Recent and Ancient, R. H. Worden and S. D. Burley, Eds., pp. 1-44, Blackwell Publishing, Oxford, 2003. 
[7] S. Morad, K. Al-Ramadan, J. M. Ketzer, and L. F. De Ros, "The impact of diagenesis on the heterogeneity of sandstone reservoirs: a review of the role of depositional facies and sequence stratigraphy," American Association of Petroleum Geologists Bulletin, vol. 94, no. 8, pp. 1267-1309, 2010.

[8] A. Fan, R. Yang, N. Lenhardt et al., "Cementation and porosity evolution of tight sandstone reservoirs in the Permian Sulige gas field, Ordos Basin (central China)," Marine and Petroleum Geology, vol. 103, pp. 276-293, 2019.

[9] B. Busch, I. Becker, B. Koehrer, D. Adelmann, and C. Hilgers, "Porosity evolution of two upper carboniferous tight-gasfluvial sandstone reservoirs: impact of fractures and total cement volumes on reservoir quality," Marine and Petroleum Geology, vol. 100, pp. 376-390, 2019.

[10] P. Ma, C. Lin, S. Zhang et al., "Diagenetic history and reservoir quality of tight sandstones: a case study from Shiqianfeng sandstones in upper Permian of Dongpu Depression, Bohai Bay Basin, eastern China," Marine and Petroleum Geology, vol. 89, pp. 280-299, 2018.

[11] J. Lai, G. Wang, S. Wang et al., "Review of diagenetic facies in tight sandstones: diagenesis, diagenetic minerals, and prediction via well logs," Earth-Science Reviews, vol. 185, pp. 234$258,2018$.

[12] D. Xiao, S. Jiang, D. Thul, S. Lu, L. Zhang, and B. Li, "Impacts of clay on pore structure, storage and percolation of tight sandstones from the Songliao Basin, China: implications for genetic classification of tight sandstone reservoirs," Fuel, vol. 211, pp. 390-404, 2018.

[13] P. Wüstefeld, U. Hilse, B. Koehrer, D. Adelmann, and C. Hilgers, "Critical evaluation of an upper carboniferous tight gas sandstone reservoir analog: diagenesis and petrophysical aspects," Marine and Petroleum Geology, vol. 86, pp. 689-710, 2017.

[14] K. E. Higgs, H. Zwingmann, A. G. Reyes, and R. H. Funnell, "Diagenesis, porosity evolution, and petroleum emplacement in tight gas reservoirs, Taranaki Basin, New Zealand," Journal of Sedimentary Research, vol. 77, no. 12, pp. 1003-1025, 2007.

[15] P. J. Dowey, D. M. Hodgson, and R. H. Worden, "Pre-requisites, processes, and prediction of chlorite grain coatings in petroleum reservoirs: a review of subsurface examples," Marine and Petroleum Geology, vol. 32, no. 1, pp. 63-75, 2012.

[16] A. Berger, S. Gier, and P. Krois, "Porosity-preserving chlorite cements in shallow-marine volcaniclastic sandstones: evidence from Cretaceous sandstones of the Sawan gas field, Pakistan," AAPG Bulletin, vol. 93, no. 5, pp. 595-615, 2009.

[17] R. H. Worden, J. Griffiths, L. J. Wooldridge et al., "Chlorite in sandstones," Earth-Science Reviews, vol. 204, article 103105, 2020.

[18] Y. Li, X. Chang, W. Yin, T. Sun, and T. Song, "Quantitative impact of diagenesis on reservoir quality of the Triassic Chang 6 tight oil sandstones, Zhenjing area, Ordos Basin, China," Marine and Petroleum Geology, vol. 86, pp. 10141028, 2017.

[19] B. E. Law, "Basin-centered gas systems," AAPG Bulletin, vol. 86, pp. 1891-1919, 2002.

[20] A. Wang, T. Liang, L. Li et al., "Origin of diagenetic calcite cements in the continental Qaidam Basin, NW China: implication for fluid flow and hydrocarbon migration," Journal of Geochemical Exploration, vol. 182, pp. 94-109, 2017.

[21] S. A. Holditch, "Tight Gas sands," Journal of Petroleum Technology, vol. 58, no. 6, pp. 86-93, 2013.
[22] C. Zou, R. Zhu, K. Liu et al., "Tight gas sandstone reservoirs in China: characteristics and recognition criteria," Journal of Petroleum Science and Engineering, vol. 88-89, pp. 82-91, 2012.

[23] G. Bada, E. Dombrádi, A. Horányi, G. Molnár, O. Sztanó, and M. Shevelev, "The algy turbidite gas play in the mak trough, pannonian Basin, Hungary," Neftyanoe Khozyaistvo - Oil Industry, vol. 5, pp. 72-76, 2014.

[24] B. Badics, A. Uhrin, I. Vető, A. Bartha, and C. Sajgó, "Basincentred gas in the Makó Trough, Hungary: a 3D basin and petroleum system modelling investigation," Petroleum Geoscience, vol. 17, no. 4, pp. 405-416, 2011.

[25] O. Sztanó, P. Szafián, I. Magyar et al., “Aggradation and progradation controlled clinothems and deep-water sand delivery model in the Neogene lake pannon, Makó Trough, Pannonian Basin, SE Hungary," Global and Planetary Change, vol. 103, pp. 149-167, 2013.

[26] I. Vető, M. Földvári, C. Sajgó, E. Thanó-Bozsó, and Z. VargaBarna, "Association of $\mathrm{H} 2 \mathrm{~S}$ - ankerite - late pyrite suggests active termochemical sulphate reducation below $5 \mathrm{~km}$ in the Pannonian Basin," in MinPet 2009' and '4th Mineral Sciences in the Carpathians, p. 171, SR Hungary, 2009.

[27] J. Mátyás and A. Matter, "Diagenetic indicators of meteoric flow in the Pannonian basin, SE Hungary," SEPM Spec.Publications, vol. 57, 1997.

[28] F. Horváth, B. Musitz, A. Balázs et al., "Evolution of the Pannonian basin and its geothermal resources," Geothermics, vol. 53, pp. 328-352, 2015.

[29] D. H. Geary, J. Rich, J. W. Valley, and K. Baker, "Isotopic evidence for salinity changes in the late Miocene Pannonian Basin; effects on the evolutionary radiation of melanopsid gastropods," Geology, vol. 27, pp. 981-985, 1989.

[30] I. Magyar, D. Radivojević, O. Sztanó, R. Synak, K. Ujszászi, and M. Pócsik, "Progradation of the paleo-Danube shelf margin across the Pannonian Basin during the Late Miocene and Early Pliocene," Global and Planetary Change, vol. 103, pp. 168-173, 2013.

[31] I. Magyar, D. H. Geary, and P. Müller, "Paleogeographic evolution of the Late Miocene Lake Pannon in Central Europe," Palaeogeography Palaeoclimatology Palaeoecology, vol. 147, no. 3-4, pp. 151-167, 1999.

[32] G. Juhász and I. Magyar, "Review and correlation of the Late Neogene (Pannonian s.l.) lithofacies and mollusc biofacies in the Great Plain, eastern Hungary," Földtani Közlöny, vol. 122, pp. 167-194, 1993.

[33] D. Zima, A. Horányi, G. Molnár, and O. Sztanó, "Hybrid event beds in lacustrine confined turbidite systems, Pannonian Basin," in 34th International Meeting of Sedimentology, Sapienza Università di Roma, 2019.

[34] E. Thamóné Bozsó, G. Juhász, and Ó. Kovács, "L. Az alföldi pannóniai s.l. képződmények ásványi összetétele I. A pannóniai s.l. homokok és homokkövek jellemzői és eredete," Földtani Közlöny, vol. 136, pp. 407-430, 2006.

[35] A. Balázs, L. Matenco, I. Magyar, F. Horváth, and S. Cloetingh, "The link between tectonics and sedimentation in back-arc basins: new genetic constraints from the analysis of the Pannonian Basin," Tectonics, vol. 35, no. 6, pp. 1526 1559, 2016.

[36] G. Tari, P. Dövényi, I. Dunkl et al., "Lithospheric structure of the Pannonian basin derived from seismic, gravity and geothermal data," Geological Society, London, Special Publications, vol. 156, no. 1, pp. 215-250, 1999. 
[37] A. Balázs, D. Granjeon, L. Matenco, O. Sztanó, and S. Cloetingh, "Tectonic and climatic controls on asymmetric half-graben sedimentation: inferences from 3-D numerical modeling," Tectonics, vol. 36, no. 10, pp. 2123-2141, 2017.

[38] L. Lenkey, P. Dövényi, F. Horváth, and S. A. Cloetingh, "Geothermics of the Pannonian basin and its bearing on the neotectonics," EGU Stephan Mueller Special Publication Series, vol. 3, pp. 29-40, 2002.

[39] B. Law, J. Edwards, R. Wallis et al., "Development of abnormally high pore pressures in a geologically young, basincentered oil and gas accumulation, Mako Trough, Hungary," American Association of Petroleum Geologists Annual Convention and Exhibition, vol. 110104, 2009.

[40] V. Dank, "Petroleum geology of the Pannonian Basin, Hungary: an overview," in The Pannonian Basin: A study in basin evolution: AAPG Memoir 45, L. H. Royden and F. Horváth, Eds., pp. 319-331, The AAPG/Datapages Combined Publications Database, 1988.

[41] G. Bada, O. Sztanó, A. Horányi, G. Molnár, and E. Dombrádi, Fúrómagok és furadékok a Makói-árok területéröl (20062014) a TXM Kft. gyüjteménye, 2015.

[42] A. Varga, V. Baranyi, B. Raucsik, and F. Schubert, “Az Endrődi Formáció kőzettani és palinológiai vizsgálata a Hódmezővásárhely-I fúrásban (Makói-árok) - őskörnyezeti és diagenezis-történeti értékelés," Földtani Közlöny, vol. 147, no. 1, p. 61, 2017.

[43] E. Nádasi, Szulfátredukció ásványtani vizsgálata a Makói-árok mélyebb részén, [M.S. thesis], University of Miskolc, 2011.

[44] J. Mátyás, Diagenesis and porosity evolution of Neogene reservoir sandstones in the Pannonian Basin (southeast Hungary), Universitat Bern, 1994.

[45] J. L. Clayton, C. W. Spencer, and I. Koncz, "Tótkomlos-Szolnok petroleum system of southeastern Hungary," in The petroleum system -from source to trap, L. B. Magoon and W. G. Dow, Eds., pp. 587-598, American Association of Petroleum Geologists Memoirs, 1994.

[46] B. Badics and I. Vető, "Source rocks and petroleum systems in the Hungarian part of the Pannonian Basin: the potential for shale gas and shale oil plays," Marine and Petroleum Geology, vol. 31, no. 1, pp. 53-69, 2012.

[47] A. Szalay and I. Koncz, "Genetic relations of hydrocarbons in the Hungarian part of the Pannonian Basin," in Generation, accumulation, and production of Europe's hydrocarbons, A. M. Spencer, Ed., pp. 317-322, EAPG Special Publication, 1991.

[48] I. Magyar, A. Fogarasi, G. Vakarcs, L. Bukó, and G. C. Tari, "The largest hydrocarbon field discovered to date in Hungary: Algyo," in The Carpathians and Their Foreland: Geology and Hydrocarbon Researces: AAPG Memoir 84, J. Golonka and F. J. Picha, Eds., pp. 619-632, 2006.

[49] J. Dickson, "Carbonate identification and genesis as revealed by staining," SEPM Journal of Sedimentary Research, vol. 36, pp. 491-505, 1966.

[50] D. M. Moore and R. C. Reynolds, "X-ray diffraction and the identification and analysis of clay minerals," Geological Magazine, vol. 135, 1997.

[51] E. Kohler and R. Wewer, "Gewinnung reiner Tonmineratkonzentrate fir die mineralogische Analyse," Keramische Zeitschrift, vol. 32, pp. 250-252, 1980.

[52] S. G. García and M. S. Camazano, "Differentiation of kaolinite from chlorite by treatment with dimethyl-sulphoxide," Clay Minerals, vol. 7, no. 4, pp. 447-450, 1968.
[53] L. G. Schultz, "Quantitative interpretation of mineralogical composition from X-ray and chemical data for the Pierre Shale," in Professional Paper, pp. C1-C31, USGS Publications Warehouse, 1964.

[54] J. M. McCrea, "On the isotopic chemistry of carbonates and a paleotemperature scale," The Journal of Chemical Physics, vol. 18, no. 6, pp. 849-857, 1950.

[55] R. L. Folk, "Stages of textural maturity in sedimentary rocks," Journal of Sedimentary Research, vol. 21, no. 3, pp. 127-130, 1951.

[56] R. L. Folk, Petrology of Sedimentary Rocks, Hemphill's, Austin, TX, USA, 1968.

[57] J. Rouquerol, D. Avnir, C. W. Fairbridge et al., "Recommendations for the characterization of porous solids (Technical Report)," Pure and Applied Chemistry, vol. 66, no. 8, pp. 1739-1758, 1994.

[58] D. Misch, D. Gross, G. Hawranek et al., "Solid bitumen in shales: petrographic characteristics and implications for reservoir characterization," International Journal of Coal Geology, vol. 205, pp. 14-31, 2019.

[59] M. Mastalerz, A. Drobniak, and A. B. Stankiewicz, "Origin, properties, and implications of solid bitumen in source-rock reservoirs: a review," International Journal of Coal Geology, vol. 195, pp. 14-36, 2018.

[60] P. D. Lundegard, "Sandstone porosity loss; a 'big picture' view of the importance of compaction," Journal of Sedimentary Research, vol. 62, no. 2, pp. 250-260, 1992.

[61] S. Gier, R. H. Worden, W. D. Johns, and H. Kurzweil, "Diagenesis and reservoir quality of Miocene sandstones in the Vienna Basin, Austria," Marine and Petroleum Geology, vol. 25, no. 8, pp. 681-695, 2008.

[62] H. G. Machel, H. R. Krouse, and R. Sassen, "Products and distinguishing criteria of bacterial and thermochemical sulfate reduction," Applied Geochemistry, vol. 10, no. 4, pp. 373389, 1995.

[63] R. T. Wilkin and H. L. Barnes, "Formation processes of framboidal pyrite," Geochimica et Cosmochimica Acta, vol. 61, no. 2, pp. 323-339, 1997.

[64] R. A. Berner, J. W. LeeuwDe, B. Spiro, D. G. Murchison, and G. Eglinton, "Sulphate reduction, organic matter decomposition and pyrite formation," Philosophical Transactions of the Royal Society of London. Series A, Mathematical and Physical Sciences, vol. 315, no. 1531, pp. 25-38, 1985.

[65] A. Balázs, E. Burov, L. Matenco, K. Vogt, T. Francois, and S. Cloetingh, "Symmetry during the syn- and post-rift evolution of extensional back-arc basins: The role of inherited orogenic structures," Earth and Planetary Science Letters, vol. 462, pp. 86-98, 2017.

[66] K. L. Milliken, "Late diagenesis and mass transfer in sandstone-shale sequences," Treatise on Geochemistry, vol. 9, pp. 181-206, 2014.

[67] S. Morad, J. M. Ketzer, and L. F. De Ros, "Spatial and temporal distribution of diagenetic alterations in siliciclastic rocks: implications for mass transfer in sedimentary basins," Sedimentology, vol. 47, pp. 95-120, 2000.

[68] J. M. McKinley, R. H. Worden, and A. H. Ruffell, "Smectite in sandstones: a review of the controls on occurrence and behaviour during diagenesis," in Clay Mineral Cements in Sandstones, pp. 109-128, Wiley, 1999.

[69] J. Mátyás, S. J. Burns, P. Müller, and I. Magyar, "What can stable isotopes say about salinity? An Example from the Late 
Miocene Pannonian Lake," Palaios, vol. 11, no. 1, pp. 31-39, 1996.

[70] L. S. Land and F. Leo Lynch, " $\delta 180$ values of mudrocks: more evidence for an 18O-buffered ocean," Geochimica et Cosmochimica Acta, vol. 60, no. 17, pp. 3347-3352, 1996.

[71] C. Lécuyer, A. Hutzler, R. Amiot et al., "Carbon and oxygen isotope fractionations between aragonite and calcite of shells from modern molluscs," Chemical Geology, vol. 332-333, pp. 92-101, 2012.

[72] T. Tarutani, R. N. Clayton, and T. K. Mayeda, "The effect of polymorphism and magnesium substitution on oxygen isotope fractionation between calcium carbonate and water," Geochimica et Cosmochimica Acta, vol. 33, no. 8, pp. 987996, 1969.

[73] J. L. Banner and G. N. Hanson, "Calculation of simultaneous isotopic and trace element variations during water-rock interaction with applications to carbonate diagenesis," Geochimica et Cosmochimica Acta, vol. 54, no. 11, pp. 31233137, 1990.

[74] M. A. S. Moraes and L. F. De Ros, "Depositional, infiltrated and authigenic clays in fluvial sandstones of the Jurassic Sergi Formation, Recôncavo Basin, Northeastern Brazil," in Origin, Diagenesis, and Petrophysics of Clay Minerals in Sandstones, D. W. Houseknecht and E. D. Pittman, Eds., pp. 197-208, 1992.

[75] M. D. Wilson, "Inherited grain-rimming clays in sandstones from eolian and shelf environments: their origin and control on reservoir properties," in Origin, Diagenesis, and Petrophysics of Clay Minerals in Sandstones, D. W. Houseknecht and E. D. Pittman, Eds., pp. 209-225, 1992.

[76] M. D. Wilson and E. D. Pittma, "Authigenic clays in sandstones; recognition and influence on reservoir properties and paleoenvironmental analysis," SEPM Journal of Sedimentary Research, vol. Vol. 47, pp. 3-31, 1977.

[77] L. J. Wooldridge, R. H. Worden, J. Griffiths, A. Thompson, and P. Chung, "Biofilm origin of clay-coated sand grains," Geology, vol. 45, pp. 875-878, 2017.

[78] R. G. Maliva, "Displacive calcite syntaxial overgrowths in open marine limestones," Journal of Sedimentary Research, vol. 59, pp. 397-403, 1989.

[79] G. C. Adelseck, G. W. Gregory, and P. Roth, "Experimental evidence for the selective dissolution and overgrowth of calcareous nannofossils during diagenesis," GSA Bulletin, vol. 84, no. 8, pp. 2755-2762, 1973.

[80] S. O. Schlanger and R. G. Douglas, "Pelagic ooze - chalk -limestone transition and its implications for marine stratigraphy," Pelagic Sediments, K. J. Hsii and C. Jenkyns, Eds., pp. 117-148, 1974.

[81] H. E. Cook and R. M. Egbert, "Diagenesis of deep-sea carbonates," in Diagenesis in Sediments and Sedimentary Rocks, 2, G. Larsen and G. V. Chilingar, Eds., pp. 213-288, Elsevier, 1983.

[82] J. Saïag, P. Y. Collin, J. P. Sizun et al., "Classifying chalk microtextures: Sedimentary versus diagenetic origin (Cenomanian-Santonian, Paris Basin, France)," Sedimentology, vol. 66, no. 7, pp. 2976-3007, 2019.

[83] A. Korecz, M. Sütőné Szentai, and I. Magyar, "Biostratigraphic revision of the HOD-I well: Hungary's deepest borehole failed to reach the base of the Upper Miocene Pannonian Stage," Geologica Carpathica, vol. 55, pp. 475-485, 2004.

[84] A. Matter, "Burial diagenesis of pelitic and carbonate deepsea sediments from the Arabian Sea," in Initial Reports of the Deep Sea Drilling Project, 23, Pascal and Francis Bibliographic Databases, 1974.

[85] L. A. Czerniakowski, K. C. Lohmann, and J. Lee Wilson, "Closed-system marine burial diagenesis: isotopic data from the Austin Chalk and its components," Sedimentology, vol. 31, no. 6, pp. 863-877, 1984.

[86] S. Hillier, J. Mátyás, A. Matter, and G. Vasseur, "Illite/smectite diagenesis and its variable correlation with vitrinite reflectance in the Pannonian Basin," Clays and Clay Mineral, vol. 43, no. 2, pp. 174-183, 1995.

[87] R. Calvo, A. Ayalon, A. Bein, and E. Sass, "Chemical and isotopic composition of diagenetic carbonate cements and its relation to hydrocarbon accumulation in the Heletz-Kokhav oil field (Israel)," Journal of Geochemical Exploration, vol. 108, no. 1, pp. 88-98, 2011.

[88] J. P. Hendry, "Geochemical trends and palaeohydrological significance of shallow burial calcite and ankerite cements in Middle Jurassic strata on the East Midlands Shelf (onshore UK)," Sedimentary Geology, vol. 151, no. 1-2, pp. 149-176, 2002.

[89] J. P. Hendry, M. Wilkinson, A. E. Fallick, and R. S. Haszeldine, "Ankerite cementation in deeply buried Jurassic sandstone reservoirs of the central North Sea," Journal of Sedimentary Research, vol. 70, no. 1, pp. 227-239, 2000.

[90] J. D. Kantorowicz, "The origin of authigenic ankerite from the Ninian Field, UK North Sea," Nature, vol. 315, no. 6016, pp. 214-216, 1985.

[91] L. González-Acebrón, J. Arribas, and R. Mas, "Role of sandstone provenance in the diagenetic albitization of feldspars," Sedimentary Geology, vol. 229, no. 1-2, pp. 53-63, 2010.

[92] G. C. Saigal, S. Morad, K. Bjorlykke, P. K. Egeberg, and P. Aagaard, "Diagenetic albitization of detrital K-feldspar in Jurassic, Lower Cretaceous, and Tertiary clastic reservoir rocks from offshore Norway, I. Textures and Origin," SEPM Journal of Sedimentary Research, vol. 58, pp. 1003-1013, 1988.

[93] R. H. Worden and S. Morad, "Quartz Cementation in Oil Field Sandstones: A Review of the Key Controversies," in Quartz Cementation in Sandstones, pp. 1-20, Wiley, 2000.

[94] P. A. Bjorkum, "How important is pressure in causing dissolution of quartz in sandstones?," SEPM Journal of Sedimentary Research, vol. 66, pp. 147-154, 1996.

[95] P. Aagaard, J. S. Jahren, A. O. Harstad, O. Nilsen, and M. Ramm, "Formation of grain-coating chlorite in sandstones. Laboratory synthesizedvs. natural occurrences," Clay Minerals, vol. 35, no. 1, pp. 261-269, 2000.

[96] S. M. C. Anjos, L. F. De Ros, and C. M. A. Silva, "Chlorite authigenesis and porosity preservation in the Upper Cretaceous marine sandstones of the Santos Basin, Offshore Eastern Brazil," in Clay Mineral Cements in Sandstones, pp. 289-316, Wiley, 1999.

[97] P. Ryan and R. Reynolds, "The chemical composition of serpentine/chlorite in the Tuscaloosa Formation, United States Gulf Coast: EDX vs. XRD determinations, implications for mineralogic reactions and the origin of anatase," Clays and Clay Minerals, vol. 45, no. 3, pp. 339-352, 1997.

[98] S. N. Ehrenberg, "Preservation of anomalously high porosity in deeply buried sandstones by grain-coating chlorite: examples from the Norwegian continental shelf," American Association of Petroleum Geologists Bulletin, vol. 77, pp. 1260-1286, 1993. 
[99] J. R. Boles and S. G. Franks, "Clay diagenesis in Wilcox sandstones of Southwest Texas; implications of smectite diagenesis on sandstone cementation," Journal of Sedimentary Research, vol. 49, pp. 55-70, 1979.

[100] A. Thomson, "Preservation of porosity in the Deep Woodbine/Tuscaloosa Trend, Louisiana," Journal of Petroleum Technology, vol. 34, no. 5, pp. 1156-1162, 2013.

[101] G. Yuan, Y. Cao, J. Gluyas et al., "Feldspar dissolution, authigenic clays, and quartz cements in open and closed sandstone geochemical systems during diagenesis: typical examples from two sags in Bohai Bay Basin, East China," AAPG Bulletin, vol. 99, no. 11, pp. 2121-2154, 2015.

[102] P. Aagaard, P. K. Egeberg, G. C. Saigal, S. Morad, and K. Bjorlykke, "Diagenetic albitization of detrital K-feldspars in Jurassic, Lower Cretaceous and Tertiary clastic reservoir rocks from offshore Norway; II, Formation water chemistry and kinetic considerations," Journal of Sedimentary Research, vol. 60, no. 4, pp. 575-581, 1990.

[103] C. Sajgó, "Organic geochemistry of crude oils from Southeast Hungary," Organic Geochemistry, vol. 6, pp. 569-578, 1984.

[104] J. Tóth and I. Almasi, "Interpretation of observed fluid potential patterns in a deep sedimentary basin under tectonic compression: Hungarian Great Plain, Pannonian Basin," Geofluids, vol. 1, no. 1, p. 36, 2001.

[105] F. Schubert, L. W. Diamond, and T. M. Tóth, "Fluid-inclusion evidence of petroleum migration through a buried metamorphic dome in the Pannonian Basin, Hungary," Chemical Geology, vol. 244, no. 3-4, pp. 357-381, 2007.

[106] H. Mansurbeg, L. F. de Ros, S. Morad et al., "Meteoric-water diagenesis in late Cretaceous canyon-fill turbidite reservoirs from the Espírito Santo Basin, eastern Brazil," Marine and Petroleum Geology, vol. 37, no. 1, pp. 7-26, 2012.

[107] M. A. K. El-ghali, K. G. Tajori, H. Mansurbeg, N. Ogle, and R. M. Kalin, "Origin and timing of siderite cementation in Upper Ordovician glaciogenic sandstones from the Murzuq basin, SW Libya," Marine and Petroleum Geology, vol. 23, no. 4, pp. 459-471, 2006.

[108] V. Schmidt and D. A. McDonald, "Secondary reservoir porosity in the course of sandstone diagenesis," in Education course note series, P. A. Scholle and P. R. Schluger, Eds., SEPM Society for Sedimentary Geology, 1979.

[109] A. Juhász, T. M. Tóth, K. Ramseyer, and A. Matter, "Connected fluid evolution in fractured crystalline basement and overlying sediments, Pannonian Basin, SE Hungary," Chemical Geology, vol. 182, no. 2-4, pp. 91-120, 2002.

[110] L. Molnár, T. M. Tóth, and F. Schubert, "Structural controls on petroleum migration and entrapment within the faulted basement blocks of Szeghalom Dome (Pannonian Basin, SE Hungary)," Geologia Croatica, vol. 68, no. 3, pp. 247-259, 2015.

[111] A. Juhász, A. Matter, and K. Ramseyer, "Distribution and stable isotopic variation of kaoliniterdickite in late Miocene sandstones, SE Hungary: implications to thermal and palaeohydrodynamic reconstructions," in 18th International Association of Sedimentologists Regional Meeting of Sedimentology, pp. 182-183, Heidelberg, Germany, 1997. 